\title{
Flagellia, a new subgenus of Haliclona (Porifera, Haplosclerida)
}

\author{
Rob W.M. VAN SOEST \\ Naturalis Biodiversity Center, P.O. Box 9517, 2300 RA Leiden, The Netherlands \\ Email: rob.vansoest@naturalis.nl \\ urn:1sid:zoobank.org:author:3F3CFEFF-E289-4B59-9C4F-6AFAE7E7C8C0
}

\begin{abstract}
Haplosclerid sponges possessing a unique asymmetric flagelliform type of sigmoid microsclere have been reported from all global oceans. This peculiar spicule, characterized by a circular or elliptical shape, with a longer and sharper curved ending at one side and a shorter and more gradually curved ending at the opposing side, is proposed to be termed 'flagellosigma'. These sponges invariably also possess smaller normal sigmas while their skeletal structure of oxea megascleres is markedly confused. They are assigned to the large genus Haliclona Grant, 1841 (family Chalinidae) in a new subgenus, Haliclona (Flagellia) subgen. nov. The species belonging to the new subgenus are reviewed and four species new to science are described, Haliclona (Flagellia) indonesiae subgen. et sp. nov., H. (F.) amirantensis subgen. et sp. nov., $H$. (F.) hiberniae subgen. et sp. nov. and $H$. (F.) hajdui subgen. et sp. nov. One species, $H$. (F.) hentscheli nom. nov., is given a new name on account of secondary homonymy caused by its transfer to the genus Haliclona. One species remains unnamed because of paucity of material. Already known species, reassigned to the new subgenus are $H$. ( $F$.) hamata subgen. et comb. nov., $H$. ( $F$.) flagellifera subgen. et comb. nov., $H$. $(F$.) porosa subgen. et comb. nov., $H$. (F.) edaphus subgen. et comb. nov. and $H$. $(F$.) anataria subgen. et comb. nov. Additional species are likely hiding among many erroneous records of 'Gellius flagellifer' from wide ranging parts of the global oceans.
\end{abstract}

Keywords. Chalinidae, flagellosigma, new species, global oceans.

Van Soest R.W.M. 2017. Flagellia, a new subgenus of Haliclona (Porifera, Haplosclerida). European Journal of Taxonomy 351: 1-48. https://doi.org/10.5852/ejt.2017.351

\section{Introduction}

The present study addresses a group of haplosclerid sponge specimens united by a remarkable type of microsclere, an asymmetrical flagellated or flagelliform sigma, which is here proposed to be named 'flagellosigma'. Specimens possessing this spicule type, which invariably also possess a smaller 'normal' sigma type, occur in many parts of the global oceans and have been routinely assigned to Gellius flagellifer Ridley \& Dendy, 1886, currently named Haliclona (Gellius) flagellifera. Additionally, several specimens with the same general spicule complement (flagellosigmas and normal sigmas) have been described as separate species ('Desmacella' porosa Fristedt, 1887, Gelliodes hamata Thiele, 1903, Gellius incrustans Hentschel, 1912, Gellius edaphus De Laubenfels, 1930, Gellius rhaphidiophorus Brøndsted, 1933 and Gellius anatarius Lévi \& Lévi, 1983). These additional species with flagellosigmas are currently mostly assigned to the subgenus Haliclona (Gellius), with the exception of Hemigellius 
porosus (Fristedt, 1887) and Gelliodes hamata. The collections of the Naturalis Biodiversity Center at Leiden incorporate a representative set of flagellosigma-bearing specimens from various parts of the world, allowing a review of the status of Haliclona (Gellius) flagellifera and its morphological siblings. Despite the superficial resemblance of all records and reports of this seemingly 'cosmopolitan species' this study demonstrates local differences in shape and spicule types and sizes, leading to the hypothesis that the flagellosigma can be considered apomorphic to a monophyletic group of sponge species, and merits recognition at the (sub)genus level. Taxonomic decisions of species status and erection of new species is done below only using collected specimens. The status of taxa discussed on the basis of reports in literature is restricted to tentative suggestions.

\section{Material and methods}

Specimens and slides of the following institutions have been studied:

- Naturalis Biodiversity Center, Leiden, The Netherlands, specimens from the collections of the former Rijksmuseum van Natuurlijke Historie (registration numbers preceded by the acronym RMNH) and the former Zoologisch Museum van de Universiteit van Amsterdam (registration numbers preceded by the acronym ZMA)

- The Natural History Museum, London (registration numbers preceded by the acronym BMNH)

- Senckenberg Museum, Frankfurt (registration numbers preceded by the acronym SMF)

- Smithsonian Institution, National Museum of Natural History (registration number preceded by acronym USNM)

- Western Australian Museum, Perth (registration number preceded by acronym WAM)

Specimen processing included making thick sections and dissociated spicule slides for light microscopic and SEM examination closely following previously described procedures (for details see Van Soest et al. 2014: 62). Length and thickness measurements are based on 25 randomly chosen spicules of each distinguished type. Measurements and shape characterization of flagellosigmas were carried out following the meristic parameters depicted in Fig.1 and described below.

\section{Definition of a flagellosigma}

A flagellosigma (Fig. 1) differs in two major aspects from sigmas in general: (1) asymmetry in the length of the opposite endings, and (2) asymmetry in the curvature of these endings. Furthermore, compared to a normal sigma the flagellosigma has the spicular axes either more or less equal or it has the length- and width axes reverted, resulting in a circular, ovoid or elliptic outline. The flagellosigma occurs only in the order Haplosclerida. Sigmas in other groups often have a slight asymmetry in the opposite endings, one being more sharply curved than the other, but their lengths are almost always equal and the shape is mostly a shallow C-shape with normally longer length axes and shorter width axes. Only in a very few cases, e.g., in Mycale (Naviculina) diversisigmata Van Soest, 1984, the shape is circular or elliptical and the two endings may have different lengths, but in that case these are more or less symmetrical in their curvature, not overtly asymmetrical (Fig. 2). The term flagellosigma is proposed to be strictly limited to sigma shapes as depicted in Fig. 1. In order to investigate the meristic and shape differences between flagellosigmas of different individuals and species, a series of measurements and qualifiers are proposed.

\section{Measurements}

1. length of the longest ending, the long axis

2. length of the shortest ending

3. width of the spicule at the widest part, usually the short axis

4. thickness of the spicule at its most outward curve 


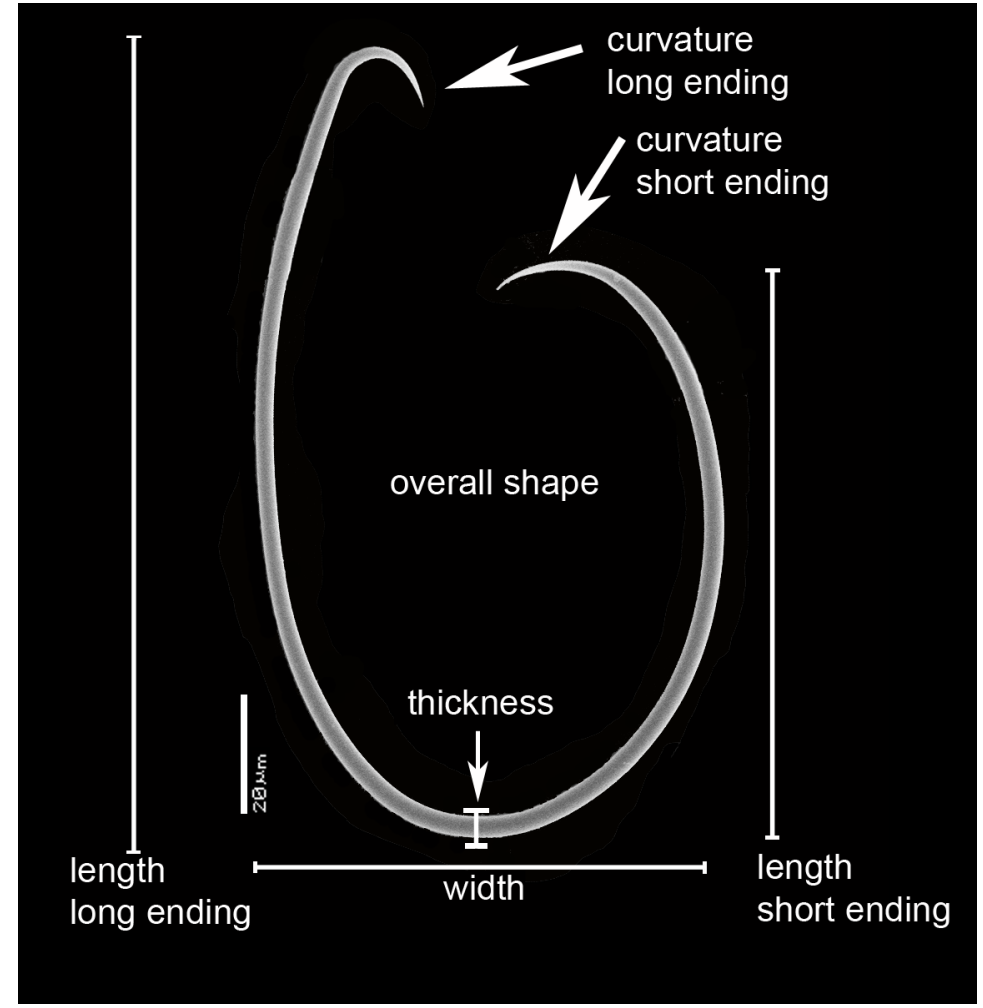

Fig. 1. Flagellosigma, the characteristic feature of Haliclona (Flagellia) subgen. nov., showing meristic and descriptive features used in this study.

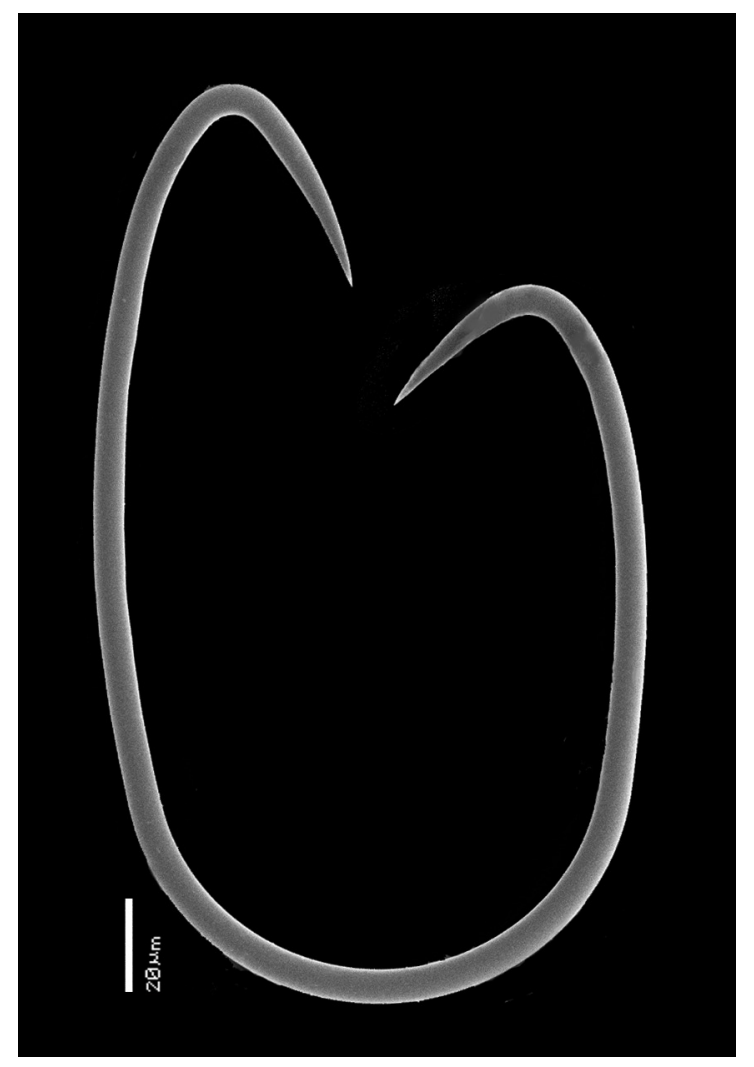

Fig. 2. 'Flagellated' sigma of Mycale (Naviculina) diversisigmata Van Soest, 1984, a sigma type superficially similar to a flagellosigma, but the morphology is considered non-homologous due to the lack of a strong asymmetry in the longer and shorter endings. 


\section{Qualifiers}

1. shape of the spicule, either circular, ovoid, or elliptical

2. curvature of the longest ending, either rounded, short-straight, long-straight, long-upturned

3. curvature of the shortest ending, either shallow or wide

\section{Taxonomic history of flagellosigma-bearing sponges}

The first description and depiction of a flagellosigma spicule is from Schmidt (1870: 53) who refers to an encrustation on Pachastrella abyssi Schmidt, 1870, from a depth of $410 \mathrm{~m}$, with robust oxeas ('stämmige Spindelnadeln') and very peculiar sigmas ("sehr eigentümliche Spangen", illustrated in pl. V, fig. 15), as an apparent Desmacella sp. These very short remarks, made in a section under the caption "Desmacella vagabunda nova species", do not actually name the encrustation, but since they follow properly named descriptions of Desmacella vagabunda Schmidt, 1870, Desmacella annexa Schmidt, 1870 and Desmacella vicina Schmidt, 1870 in the same section, it is reasonable to assume Schmidt meant the unnamed sponge to belong to his genus Desmacella Schmidt, 1870.

Schmidt's description of Desmacella vagabunda leaves no doubt that this is a proper Desmacella with tylostyles ("Stecknadeln") and sigmas ("Spangen") (which were of widely different sizes between 14 and $100 \mu \mathrm{m}$ ). The same applies to the description of $D$. annexa, which he said was a variety with the same spicules as $D$. vagabunda, but with thin oxea-like spicules added to the complement. I was able to study a slide of the type (BMNH 1870.5.3.29, Florida, $195 \mathrm{fthms}$ ) and can confirm the properties of this Desmacella. D. vicina is likewise described with tylostyles and sigmas (but these are only limited to two size variations), confirmed by the study of two slides of Schmidt's collection (BMNH 1870.5.3.40, BMNH 1870.5.3.113). The locality for Desmacella vagabunda is given as Florida, D. annexa likewise ("von ebendaher", and Schmidt's BMNH slide reads "Florida"), but no localities are given for D. vicina (nevertheless Schmidt's BMNH slide also says "Florida") and the flagellosigma-bearing $D$. sp. However the latter was encrusting the Caribbean species Pachastrella abyssi, which allows the conclusion that this also concerns a species from the Central West Atlantic region, probably Florida.

Vosmaer (1880: 108) assigned Schmidt's Desmacella vagabunda to the genus Desmacodes Schmidt, 1870 , for which he devised a new concept containing species from many different genera and families. He correctly defined D. vagabundus as having tylostyles ("tr".ac") and sigmas (" $\infty$ "). Several years later, Vosmaer (1885: 28) reassigned D. vagabunda to the genus Gellius Gray, 1867, as 'XXX. Gellius vagabundus (O.S.) Vosm.', stating that Gellius has priority over Desmacodes. He also redescribed the species vagabundus, in a very loose and frustrating way, based on extensive material collected by the Willem Barents Expeditions (1878-1882) in the Barents Sea. He maintained that the species is quite variable and assigned specimens with tylostyles, styles and oxeas, and with or without sigmas, to it. The species would also have a very large distribution. In the Barents Sea material, he distinguished three varieties $\alpha, \beta$ and $\gamma$, the latter of which was described as having the spiculation of oxeas, flagellosigmas and small normal sigmas (cf. illustrations in Vosmaer 1885: pl. V, figs 36-38) (see further below).

Ridley \& Dendy (1886: 333; 1887: 42, pl. XIII, figs 5, 10) described Gellius flagellifer from the Southern Indian Ocean (off Marion Island) from a depth of 90-135 m. In their remarks they referred to Vosmaer's Gellius vagabundus var. $\gamma$, and tentatively assigned this to their new species (pointing out that Gellius vagabundus sensu Schmidt is a Desmacella). They apparently were unaware of Schmidt's (1870: pl. V, fig. 15) drawing of a flagellosigma very similar to that found in their new species.

Fristedt (1887: 440, pl. 24 figs 36-37, pl. 28 fig. 15), unaware of Ridley \& Dendy’s G. flagellifer, described Desmacella porosa from Arctic waters, Davis Strait, $126 \mathrm{~m}$ depth. He referred to Schmidt (1870: pl. V fig. 15) to demonstrate the similarity of the flagellosigmas in Schmidt's and his own species. Fristedt did not mention the presence of small normal sigmas in his specimen. 
Lambe (1896: 185, pl. I fig. 4) reported Gellius flagellifer from the Gulf of St. Lawrence, Eastern Canada, at a depth of 68-136 m, in the process synonymizing Desmacella porosa with it. This record was mentioned by De Laubenfels (1949: 38) and Gosner (1971).

Topsent (1896: 281, pl. VIII fig. 4) reported Gellius flagellifer from the nearby Gulf of Biscay off the coast of SW France, depth $400 \mathrm{~m}$. He did not mention the presence of small normal sigmas (but see below).

Lundbeck (1902: 71, pl. II fig. 9, pl. XIV figs 1 and 73, pl. XIV fig. 2) reported both Gellius flagellifer (Lundbeck 1902: 71, from a locality between SE Iceland and the Faroe Islands, $756 \mathrm{~m} \mathrm{depth}$ ) and Desmacella (as Gellius) porosa (Lundbeck 1902: 73), one specimen from a locality off the N coast of Iceland at a depth of $214 \mathrm{~m}$, the other from an unknown depth between Iceland and the Faroe Islands. Lundbeck maintained that there were differences between the two species, and reassigned specimens reported by Topsent and Lambe to G. porosus. Burton (1959a: 19) listed Lundbeck's record of Gellius flagellifer as Haliclona flagellifer in his catalogue of the sponges of Iceland, without referring to or mentioning G. porosus.

Thiele (1903: 942, fig. 7) described the finger-shaped Gelliodes hamata from the shallow-water off Ternate, Indonesia, which combined flagellosigmas and smaller normal sigmas with a spongin enforced reticulation of oxeas. He referred to the similarity of the flagellosigmas to those of Gellius flagellifer, but the skeletal structure appeared different enough to him to distinguish them at the genus and species level.

Topsent (1904: 231) reported Gellius flagellifer from the Azores, at a depth of 845-1360 m, and this time properly mentioned the presence of normal sigmas, admitting that they were also present in the sample from the Gulf of Biscay, reported in 1896 (see above).

Lundbeck (1909: 434) reported Gellius porosus from several localities off the coast of East Greenland, at depths of 90-252 m. No descriptive information was provided.

Hentschel (1912: 390, pl. XV fig. 3, pl. XXI fig. 45) described a small encrusting species Gellius incrustans, possessing flagellosigmas, from the Aru Islands, Indonesia, depth $12 \mathrm{~m}$. He pointed out the similarity with Gellius flagellifer, but judged that the spicule size differences were sufficient for specific distinctness.

Hentschel (1916: 11) reported Gellius porosus from Spitsbergen (Svalbard), depth 141-147 m. No taxonomic information was provided.

Hentschel (1929: 978) summarized the occurrence of Gellius flagellifer and Gellius porosus in the Arctic region, relying on Lundbeck (1902), without providing additional data.

Stephens (1916: 233; 1917: 5; 1921: 5) extensively described specimens of Gellius flagellifer from off the W coast of Ireland, at depths of 90-1328 m. She supported the synonymization of Gellius porosus with it.

Ferrer Hernandez (1918: 22, fig. 3) reported Gellius porosus from off the coast of Asturias, N Spain, at $200 \mathrm{~m}$ depth. He attempted to distinguish it from Gellius flagellifer on the shape of the flagellosigmas. Ferrer Hernandez (1923: 262) listed both species without further data from all coasts of Spain.

Dendy (1922: 26) described Gellius flagellifer from Saya de Malha in the W Indian Ocean, at a depth of $99 \mathrm{~m}$. He believed that the species was cosmopolitan and that G. porosus is a synonym.

Babič (1922: 228, fig. H) remarkably reverted back to Vosmaer's nomenclature and used the name Gellius vagabundus for a flagellosigma-bearing specimen from the Adriatic Sea, depth $45 \mathrm{~m}$. 
Rezvoi (1924: 243) recorded Gellius porosus from the Kara Sea, Siberia, at a depth of $106 \mathrm{~m}$. He did not mention small normal sigmas. A few years later, Rezvoi (1928: 91) described, from the nearby Barents Sea, both Gellius porosus (which this time was described to contain small 'symmetric' sigmas as well as flagellosigmas), depth range $92-183 \mathrm{~m}$, and Gellius flagellifer, from 91-769 m. The two species were separated on spicule size data.

Dendy (1924: 320) briefly described Gellius flagellifer from Three Kings Island, New Zealand, at a depth of $180 \mathrm{~m}$. Bergquist \& Warne (1980: 22) and Kelly et al. (2009: 44) confirmed this record (as Sigmadocia flagellifer).

Topsent (1928: 314), as Babič before him, took the erroneous view that his earlier reports on Gellius flagellifer were part of what he considered to be Gellius vagabundus (Schmidt, 1870), referring to Vosmaer as the inspiration for this. In fact, Topsent's (1928) description of 'Gellius vagabundus' from 1378 m near São Miguel, Azores, is likely to be a different species from his other described specimens as the sigmas appear dissimilar to the flagellosigmas discussed here. It is possible that this could be a species of Haliclona (Gellius).

Burton (1928: 114) described two specimens as Gellius flagellifer from the Andaman Sea, from depths of 310-896 m. This record was repeated by Pattanayak (1999: 450). The same material was reexamined by Pattanayak (2006: 74, pl. IXA, text-fig. 51a-c), but fig. 51a-c does not show a proper flagellosigma rendering this record uncertain.

Burton (1930) listed Gellius flagellifer from Hammerfest, N Norway, without further data.

De Laubenfels (1930: 28; 1932: 111, fig. 66) described Gellius edaphus from an intertidal cave off the coast of Southern California, depth approximately $0-1 \mathrm{~m}$. He did not distinguish flagellosigmas and normal sigmas, but a redescription of the type material by Lee et al. (2007: 110, as Xestospongia edapha) revealed their presence.

Brøndsted (1933: 18, fig. 7) described Gellius rhaphidiophorus from the Davis Strait, W Greenland, from a depth of $410 \mathrm{~m}$. The fragments were similar to previous reports of Gellius porosus and Gellius flagellifer from the Davis Strait, but according to the author the specimen has raphides (not in dragmata).

Burton (1938: 7) reported Adocia flagellifer from a depth of $36 \mathrm{~m}$ in the Commonwealth Bay, East Antarctic. He provided some information on the flagellosigmas. Koltun (1964: 103, translated in 1966: 102) repeated this record.

Dickinson (1945: pl. 14 fig. 27-28, pl. 15 fig. 29) described Sigmadocia edaphus from Baja California (Mexico), at a depth of $120 \mathrm{~m}$. Green \& Bakus (1994: 46, fig. 27) reported this species from Southern California, at a depth of $200 \mathrm{~m}$.

Koltun (1959) reported both Gellius flagellifer [3 specimens examined on p. 212 and fig. 170 (p. 255 in the translated version)], depth 91-137 m, and Gellius porosus [37 specimens examined on p. 213 and fig. 171 (p. 256 in the translated version)], depth 51-300 m, both from the Arctic and Northwest Pacific shores of Russia. From the brief description and fig. 170 it is clear that his record of Gellius flagellifer is not correct, as he omitted to mention and depict the presence of flagellosigmas. Some years later, Koltun (1962: 186) reported Haliclona porosus from the Paramushir Islands, NW Pacific (see also Hoshino 1987).

Burton (1959b: 218) briefly described specimens named Haliclona flagellifera obtained in the Southern Red Sea (at $26 \mathrm{~m}$ depth) and near the Maldives, at a depth of $229 \mathrm{~m}$. 
Vacelet (1969: 209) described Gellius flagellifer from the Western Mediterranean, at depths of 146$270 \mathrm{~m}$. Similar records from the Mediterranean, partially as Sigmadocia flagellifer or Haliclona (Gellius) flagellifer(a), were made by Pulitzer-Finali (1978: 80; 1983: 585), Pansini (1987: 51), Longo et al. (2005: 1350) and Sitjà \& Maldonado (2014: table 6), all records combined from depths of 20-809 m.

Vacelet et al. (1976: 83, fig. 62) described and figured Gelliodes flagellifer from the reefs of Southwestern Madagascar at a depth of $37 \mathrm{~m}$.

Hoshino (1981: 118, pl. 5, fig. 2, text-fig. 45) described Sigmadocia vagabunda from Japan, depth 15-20 m, encrusting a Myxilla. It has quite large flagellosigmas (up to $270 \mu \mathrm{m}$ in the longest axis).

Boury-Esnault \& Van Beveren (1982: 111, pl. XVIII, fig. 72, text-fig. 34) described Gellius flagellifer from Kerguelen, from a depth of $195 \mathrm{~m}$.

Lévi \& Lévi (1983: 976, fig. 37) described Gellius antarius from New Caledonia, from depths of 430$500 \mathrm{~m}$, distinguished from other species with flagellosigmas by the shape and the larger size of the spicules. Some years later, Lévi (1993) reported Gellius flagellifer from New Caledonia, at depths of 495-515 m. He did not compare these two species in detail.

Uriz (1987: 68, fig. 9c; 1988: 94, pl. 23 fig. a, text-fig. 69) described Gellius flagellifer from Namibia, SE Atlantic, from depths of 183-290 m.

Sim \& Kim (1988: pl. 2, figs 3-4) reported Gellius edaphus from South Korea, at a depth of $145 \mathrm{~m}$. No normal sigmas are reported and the flagellosigmas are only $36-52 \mu \mathrm{m}$ in the longest axis.

Pulitzer-Finali (1993: 327) reported Sigmadocia flagellifer from off Mombasa, Kenya, at depths of $117-138 \mathrm{~m}$, encrusting Asteropus.

Ginn et al. (1998: 1099) mentioned the presence of Hemigellius sp. aff. flagellifer in the Bay of Fundy, E coast of Canada, at a depth of 15 m, based on Ginn's thesis (Ginn 1997: 76, fig. 14d). However, in the latter description the presence of toxas and only normal sigmas was shown, rendering the record incorrect.

Pansini \& Sarà (1999: table 1) listed Gellius flagellifer from the Straits of Magellan, at a depth of $110 \mathrm{~m}$. They did not provide descriptive data.

Gulliksen et al. (1999: 46, 81) listed Gellius porosus from Svalbard. Lemke (2003: 61) reported this species from Jan Mayen and Vesterbanken. Both were presented in lists, without description.

Samaai \& Gibbons (2005: 84, pl. 6A, text-fig. 60) described and figured Haliclona (Gellius) flagellifer from South Africa, Atlantic coast, depth $15 \mathrm{~m}$. These authors also drew attention to a record by Lévi (1969: 969, fig. 8b) of Gellius flagellifer from the Vema Seamount, but judging from the description and the illustration there are no proper flagellosigmas.

An online list of sponges from British Columbia lists Sigmadocia edaphus and Sigmadocia porosa from that region, see http://ibis.geog.ubc.ca/biodiversity/efauna/documents/SpongesofBC.pdf. According to Lehnert \& Stone (2016: table 6) that same source also suspected the occurrence of $H$. (G.) porosa (as Hemigellius porosus) in the Bering Sea and the Gulf of Alaska.

Göcke \& Janussen (2013: 83, fig. 20) extensively described and figured Haliclona (Gellius) flagellifera from the East Weddell Sea, Antarctica, depth $601 \mathrm{~m}$. 
Van Soest (2017) described and figured Haliclona (Gellius) sp. aff. flagellifera from the Guyana shelf, off the coast of Suriname, N South America, depth $130 \mathrm{~m}$. He also mentioned the existence of a sample with flagellosigmas from reefs off Santa Marta, Colombia, depth $20 \mathrm{~m}$. Van Soest (1980: 25) and De Weerdt (2000: 64) reported the existence of a specimen in the collection of the Natural History Museum, London (BMNH 1937.11.26.16a), from Turneffe Island, Belize. Alcolado (2002: 67, based on Kaminskaya 1971) gave a description of a Haliclona sp. from Cuba with flagelliform sigmas. These records indicate a widespread occurrence in the Western Atlantic.

From this literature review it is clear that sponges sharing the spicule complement of oxeas, flagellosigmas and small normal sigmas have been been reported from all over the world (Arctic, Antarctic, North Atlantic, Mediterranean, Central West Atlantic, SE Atlantic, Southern Ocean, Western Indian Ocean, Indo-West Pacific, NW Pacific, NE Pacific, East Pacific and SE Pacific). The Marine Ecoregions (sensu Spalding et al. 2007) that yielded reliable reports of specimens of Haliclona (Flagellia) subgen. nov., are presented in Fig. 3. So far, there have been five species named with flagellosigmas, but from the ubiquitous reports of one of them, H. (G.) flagellifera, it is likely that several more such species await to be recognized. The skeletal structure of most of these species conforms to the subgenus Haliclona (Gellius) as defined by De Weerdt $(1986,2002)$, but at least one species has spongin enveloped polyspicular fibers, unlike those of Haliclona (Gellius). It is not unreasonable to hypothesize that these species and specimens possessing the complement of oxeas, flagellosigmas and normal sigmas, distributed globally, form a monophyletic subset of Haliclona to be recognized here at the subgenus level and named Flagellia subgen. nov. The new subgenus differs from Haliclona (Gellius) as defined by De Weerdt $(1986,2002)$ in the possession of flagellosigmas.

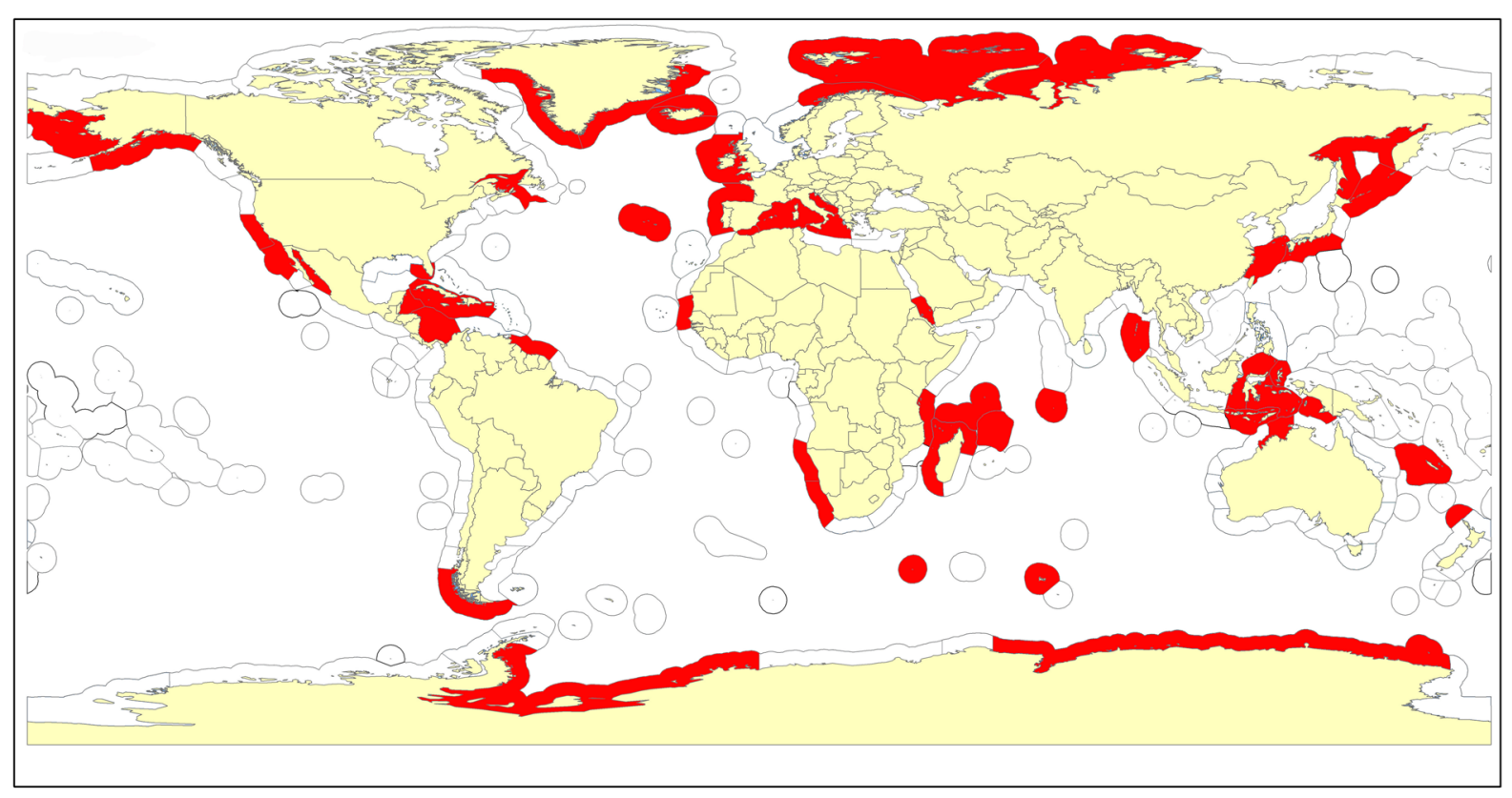

Fig. 3. Distribution of Haliclona (Flagellia) subgen. nov. in the marine ecoregions of the world (MEOWs, cf. Spalding et al. 2007), marked in red, depicting where one or more records assignable to Haliclona (Flagellia) subgen. nov. are known to date. Map courtesy of World Wildlife Fund (2012). 


\title{
Results
}

\section{Systematic descriptions}

The order in which the species are treated is geographic, starting with Indonesia, then Western Indian Ocean, followed by Central West Atlantic, North Atlantic, and ending with the Eastern Pacific.

\author{
Phylum Porifera Grant, 1836 \\ Class Demospongiae Sollas, 1885 \\ Subclass Heteroscleromorpha Cárdenas, Pérez \& Boury-Esnault, 2012 \\ Order Haplosclerida Topsent, 1928 \\ Family Chalinidae Gray, 1867 \\ Genus Haliclona Grant, 1841 \\ Flagellia subgen. nov. \\ urn:Isid:zoobank.org:act:B6ABC6E8-EF63-4D79-A636-B3348CC80D3A
}

\section{Type species}

Haliclona (Flagellia) indonesiae subgen. et sp. nov.

\section{Etymology}

The name is derived from the Latin word 'flagellum', meaning 'whip', which refers to the whip-like flagellosigma.

\section{Diagnosis}

Haliclona-like sponges possessing a spiculation of oxeas, flagellosigmas (asymmetrical sigmas with unequal length and unequal shape of inward curved endings) and symmetrical (normal-shaped) sigmas. Skeletal reticulation loosely organized, unispicular, paucispicular or polyspicular, bound by variable amounts of spongin.

\section{Remarks}

This subgenus shares with mainstream Haliclona species a skeleton in which the ascending spicule tracts are interconnected by single megascleres. There is usually no distinct detachable ectosomal skeleton, although tangential arrangement of the oxeas at the surface is common. The choanosomal skeleton tends to be very loosely organized, verging to confused. In that aspect it conforms most closely to species of the subgenus Gellius, but in that subgenus the sigmas are symmetrical and often angular. Although symmetrical normal sigmas are part of the spicule complement of the new subgenus, these are never angular. The habitus of members of the subgenus varies strongly, from small crusts to elaborate plates or arborescent forms. Association with other sponges or other sessile organisms appears common.

The subgenus is found all over the world's oceans. The depth occurrence is wide, but so far is confined to coastal, continental platform and upper bathyal waters.

Ten species are recognized here, four of which are new to science, one is given a new name due to junior homonymy, and one remains unnamed due to limited available material. From the historical overview presented above it is likely that several more species will be found to be extant.

It would perhaps have been logical to choose Haliclona (Flagellia) flagellifera as the type species for the new subgenus as it is the most closely associated name to species belonging to Flagellia subgen. nov. (cf. the historical overview above). However, the holotype of $H$. (F.) indonesiae sp. nov. was collected 
recently and is also quite large in size making subsampling for DNA sequencing a viable option for nearfuture phylogenetic studies of the position of Flagellia subgen. nov. in the order Haplosclerida.

Haliclona (Flagellia) indonesiae subgen. et sp. nov. urn:1sid:zoobank.org:act:FB7CAF59-769C-491C-B5AE-BB37E5C5121C

Figs $4-5$

\section{Etymology}

Named after the country where the holotype was collected.

\section{Material examined}

Holotype

INDONESIA: North Sulawesi, Manado, coral reef, depth $18 \mathrm{~m}$, coll. N.J. de Voogd, field number MD09/160502/061, 16 May 2002 (RMNH Por. 2326).

\section{Paratype}

INDONESIA: Ambon, Ambon Bay near Eri, $3.75^{\circ} \mathrm{S}, 128.1333^{\circ} \mathrm{E}$, sandy bay with patch reefs, depth 4-6 m, coll. R.W.M. Van Soest, field number 006/III/15, 5 Sep. 1984 (ZMA Por. 08160).

\section{Additional specimens examined}

INDONESIA: Lesser Sunda Islands, Lombok, Bay of Pidjot, $8.8108^{\circ} \mathrm{S}, 116.5224^{\circ} \mathrm{E}, 22 \mathrm{~m}$ depth, dredge, coll. Siboga Exped. stat. 033, 24 Mar. 1899 (ZMA Por. 01233); Lesser Sunda Islands, Sumba, Bay of Nangamessi, $9.6456^{\circ} \mathrm{S}, 120.2642^{\circ}$ E, 0-36 m depth, dredge, coll. Siboga Exped. stat. 053, 21 Apr. 1899 (ZMA Por. 01234); Timor Leste, Timor, S coast, $8.6566^{\circ} \mathrm{S}, 127.0733^{\circ} \mathrm{E}, 34 \mathrm{~m}$ depth, dredge, coll. Siboga Exped. stat. 285, 18 Jan. 1900 (ZMA Por. 01235).

AUSTRALIA: a likely Australian specimen (unpublished, not examined by me, identification based on in situ, on deck and light microscopic images provided), NW Australia, Woodside Kimberley Survey 2012, station 115/K12, depth 16.6 m, coll. O.A. Gomez, 22 Oct. 2012 (WAM Z54639).

\section{Description}

The holotype (Fig. 4A, A1, A2) is a large plate-like sponge, tending to form a very shallow cup with folding sides. Size $25 \times 20 \mathrm{~cm}$, less than $1 \mathrm{~cm}$ thick. Color pinkish cream alive, orange-cream in alcohol. Surface smooth, riddled with rounded holes in life, but these contract in alcohol. A few oscules of about $5 \mathrm{~mm}$ are present. Consistency firm. The paratype (Fig. 4B) is broken into three flat fragments, but together these comprise also a large plate-like sponge. The life color was noted as light brown, but in alcohol it is slightly darker brown. Surface is similarly smooth and no oscules are apparent. The additional specimens are smaller flat encrustations.

Skeleton (Fig. 5A-B). A confused system of pauci- to polyspicular ascending spicule tracts and interconnecting spicules. Superficial spicule tracts are often consolidated by some spongin, which occasionally envelops tracts entirely, but interiorly spongin is rare and only binding. Loose megascleres are common.

OXEAS (Fig. 5C-C1). Curved, sharply pointed, 189-249-318 × 8-12.4-18 $\mu \mathrm{m}$.

Flagellosigmas (Fig. 5D-E). Predominantly circular or ovoid. Curvature of long ending rather sharply bent and long upturned (Fig. 5D1), of short ending deeply bent (Fig. 5D2), varying from narrow to wide. 

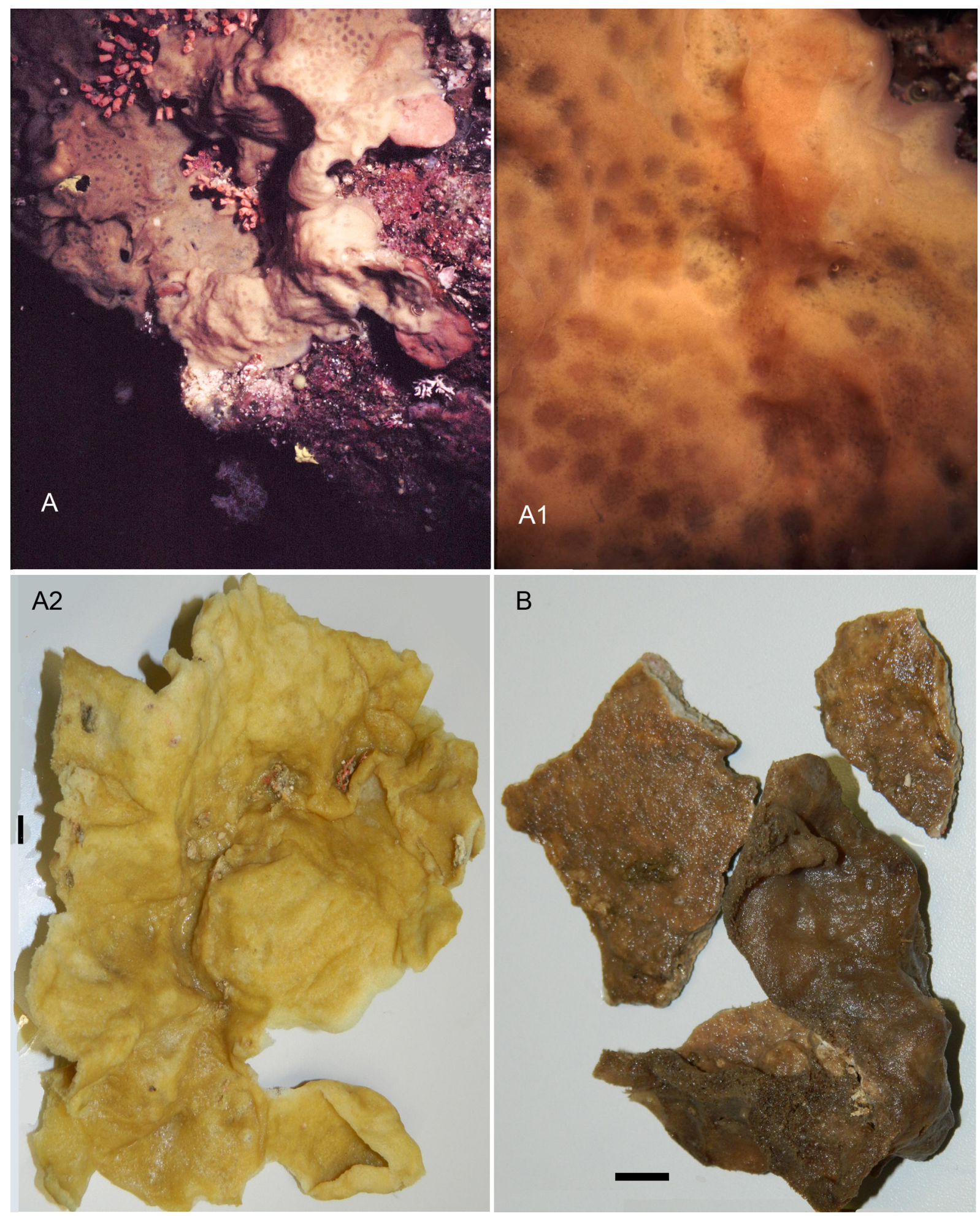

Fig. 4. Haliclona (Flagellia) indonesiae subgen. et sp. nov. A. Holotype (RMNH Por. 2326) in situ at Manado, North Sulawesi, Indonesia. $\mathbf{A}_{1}$. Detail of surface of in situ holotype. $\mathbf{A}_{2}$. Preserved holotype specimen (scale bar $=1 \mathrm{~cm}$ ). B. Fragmented paratype (ZMA Por. 08160) from Ambon, Indonesia (scale bar $=1 \mathrm{~cm})$. 


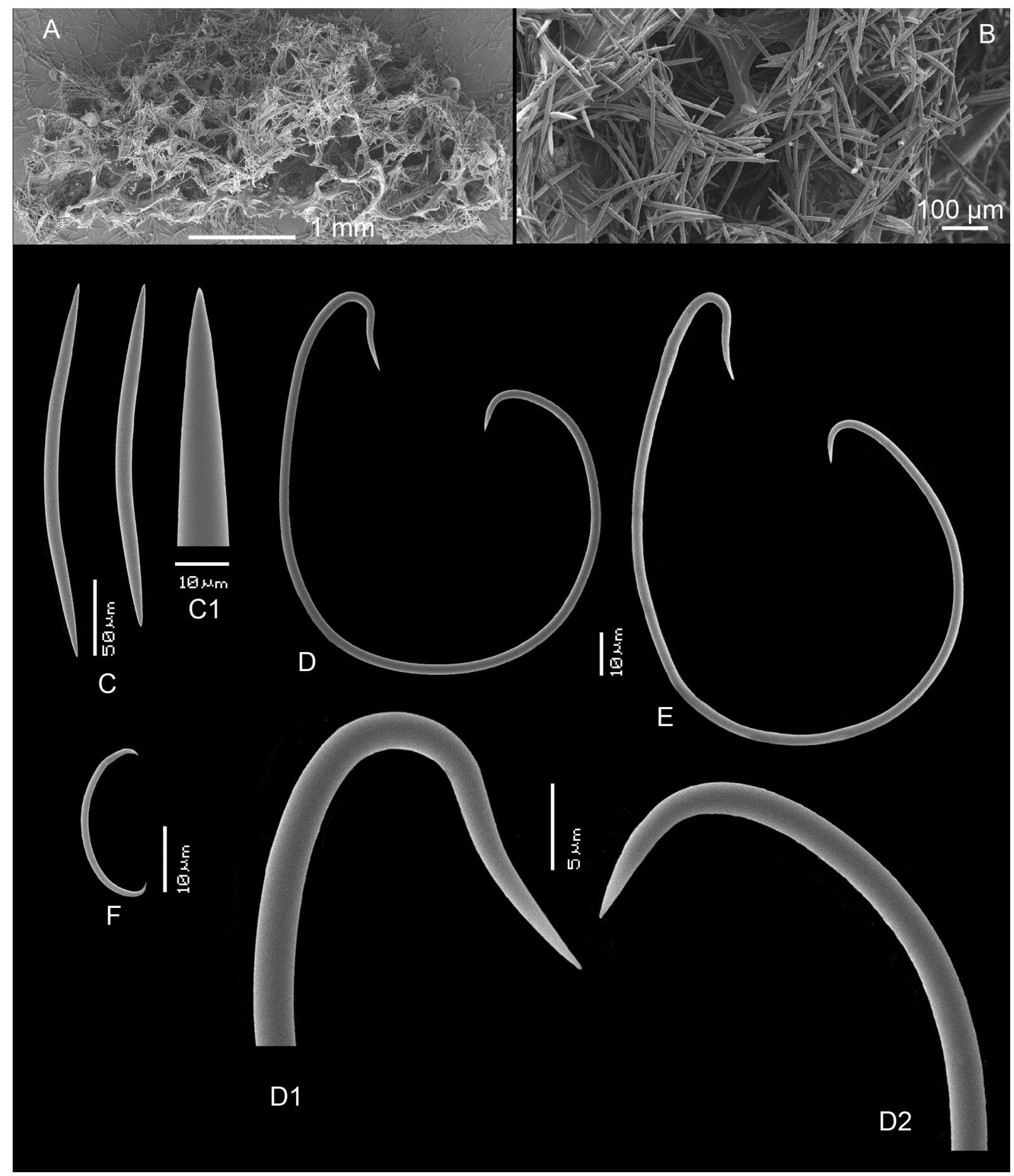

Fig. 5. Haliclona (Flagellia) indonesiae subgen. et sp. nov., holotype (RMNH Por. 2326). A. SEM image of cross section. B. SEM image of surface. C-F. SEM images of spicules. C. Oxeas. $\mathbf{C}_{\mathbf{1}}$. Detail of one of the apices. D-E. Flagellosigmas. $\mathbf{D}_{1}$. Detail of long ending of flagellosigma. $\mathbf{D}_{2}$. Detail of short ending of flagellosigma. F. Sigma. 
In a single large size range, length of long ending 85-101-114 $\mu \mathrm{m}$, length of short ending 58-69-77 $\mu \mathrm{m}$, width $63-78-87 \mu \mathrm{m}$, thickness $1.5-2.1-2.5 \mu \mathrm{m}$.

Normal Sigmas (Fig. 5F). A single category, small and thin, in a large size range, but not clearly divisible, $14-25.6-42 \times 0.5-0.94-1.5 \mu \mathrm{m}$

\section{Distribution and ecology}

Indonesia: Manado, Ambon, Lesser Sunda Islands (Lombok, Sumba); Timor Leste; NW Australia (Marine Ecoregions Celebes Sea, Banda Sea, Lesser Sunda, Bonaparte Coast), on reefs at depths of 4-36 m.

\section{Remarks}

In spicule shapes and sizes the new species is extremely close to Indonesian Haliclona (Flagellia) hamata (Thiele, 1903) (see below). The shapes and sizes of the flagellosigmas are virtually identical, and the length of the small normal sigmas is similar. However, there are three distinct differences: the body shape of $H$. (F.) hamata is digitate to arborescent, the oxeas are larger and especially thicker (264-425 $\times 13-24 \mu \mathrm{m})$, and the normal sigmas are considerably more robust (thickness $1.5-2.5 \mu \mathrm{m}$ ). The combination of these differences confirms the specific status of the two sympatric species. A third Indonesian species $H$. (F.) hentscheli nom. nov. (see below) differs clearly in having two size categories of flagellosigmas and normal sigmas, and smaller and thinner oxeas.

The presence of this species in NW Australia is here reported on the basis of a photo of an in situ specimen, a photo of an 'on deck' labeled fragment of that specimen, and a light microscopic photo of the skeleton and spicules made from the fragment. These images were graciously provided by one of the manuscript reviewers. Although I did not study the material myself, the images provided sufficient evidence for a positive identification as Haliclona (Flagellia) indonesiae subgen. et sp. nov.

Haliclona (Flagellia) hamata (Thiele, 1903) subgen. et comb. nov. Figs 6-8

Gelliodes hamata Thiele, 1903: 942, fig. 7.

\section{Material examined}

INDONESIA: fragment of holotype, Halmahera, Ternate, shallow depth (SMF 1640); Papua, Aru Islands, Pearl Banks, anchorage off Pulu Jedan, 5.4134 ${ }^{\circ}$ S, $134.6677^{\circ}$ E, $13 \mathrm{~m}$ depth, trawl, coll. Siboga Exped. stat. 273, 23 Dec. 1899 (ZMA Por. 03041); Nusa Tenggara, NE coast of Sumba, 9.95 ${ }^{\circ} \mathrm{S}, 120.8^{\circ} \mathrm{E}, 50 \mathrm{~m}$ depth, coll. R.W.M. Van Soest, Agassiz trawl, Snellius II Exped. stat. 068/V/16, 16 Sep. 1984 (ZMA Por. 09050a); Nusa Tenggara, NE coast of Sumba, $9.95^{\circ}$ S, $120.8^{\circ}$ E, $50 \mathrm{~m}$ depth, coll. R.W.M. Van Soest, dredge, Snellius II Exped. stat. 068/V/12, 16 Sep. 1984 (ZMA Por. 09285).

\section{Description}

From a thickly encrusting base, the sponge issues upright branches, which may divide higher up. In the holotype these finger-shaped digitations are 2-2.5 $\times 0.7 \mathrm{~cm}$ in size (Thiele 1903), in ZMA 09285 (Fig. 7) the branches are up to $13 \mathrm{~cm}$ long and $1 \mathrm{~cm}$ in diameter, in ZMA Por. 09050a there are only lumpy fragments. The color is light brown or yellow-brown, both in situ and in alcohol. Surface optically smooth, with a few flush oscules of about $3 \mathrm{~mm}$ in diameter. There are encrusting bryozoans and hydroids (the holotype is described as bearing small stones and other foreign particles). Consistency firm. 
SKELETON. Spongin encased fibers cored by one or mores oxeas are common, especially in the superficial region. Overall skeletal structure is a confused reticulation. Microscleres are relatively rare.

OxEAS (Figs 6A-A1, 8A-A1). Curved, fusiform, robust, sharply pointed, 264-343-425 × 13-18.1$24 \mu \mathrm{m}$.

Flagellosigmas (Figs 6B-C, 8B-C). Predominantly circular to ovoid, with the long ending sharply curved and long-upturned, the short ending with narrow curve, in a single size range. Length of long-

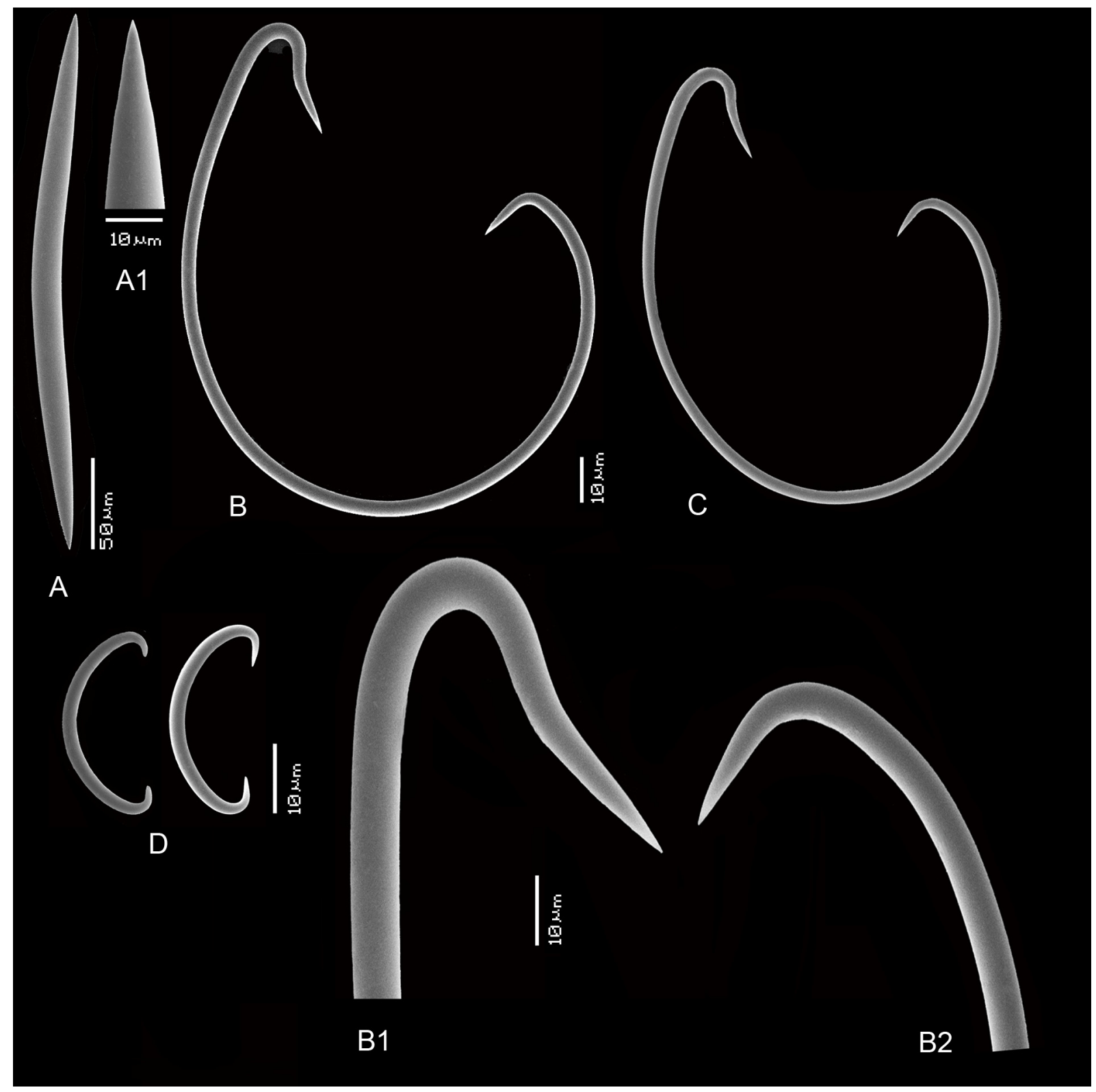

Fig. 6. Haliclona (Flagellia) hamata (Thiele, 1903) subgen. et comb. nov., SEM images from a fragment of the holotype (SMF 1640) from Ternate, Indonesia. A. Oxea. A. Detail of one of the apices. B-C. Flagellosigmas. $\mathbf{B}_{1}$. Detail of long ending of flagellosigma. $\mathbf{B}_{2}$. Detail of short ending of flagellosigma. D. Sigmas. 
ending 64-103-130 $\mu \mathrm{m}$ (holotype: 64-110 $\mu \mathrm{m}$ ), length of short ending 40-76-96 $\mu \mathrm{m}$ (holotype 40$81 \mu \mathrm{m}$ ), width 44-89-108 $\mu \mathrm{m}$ (holotype 44-95 $\mu \mathrm{m}$ ), thickness 2-2.8-4 $\mu \mathrm{m}$ (holotype 2-3.5 $\mu \mathrm{m}$ ).

Normal sigmas (Figs 6D, 8D). Small, robust, in a limited size range, 15-26.1-39 $\times 1.5-2.3-3 \mu \mathrm{m}$ (holotype: $15-33 \times 2-2.5 \mu \mathrm{m}$ ).

\section{Distribution and ecology}

Indonesia: Ternate, Aru Islands, Sumba (Marine Ecoregions Halmahera, Arafura Sea and Lesser Sunda), on reefs and sand bottoms, shallow water down to $50 \mathrm{~m}$ depth.

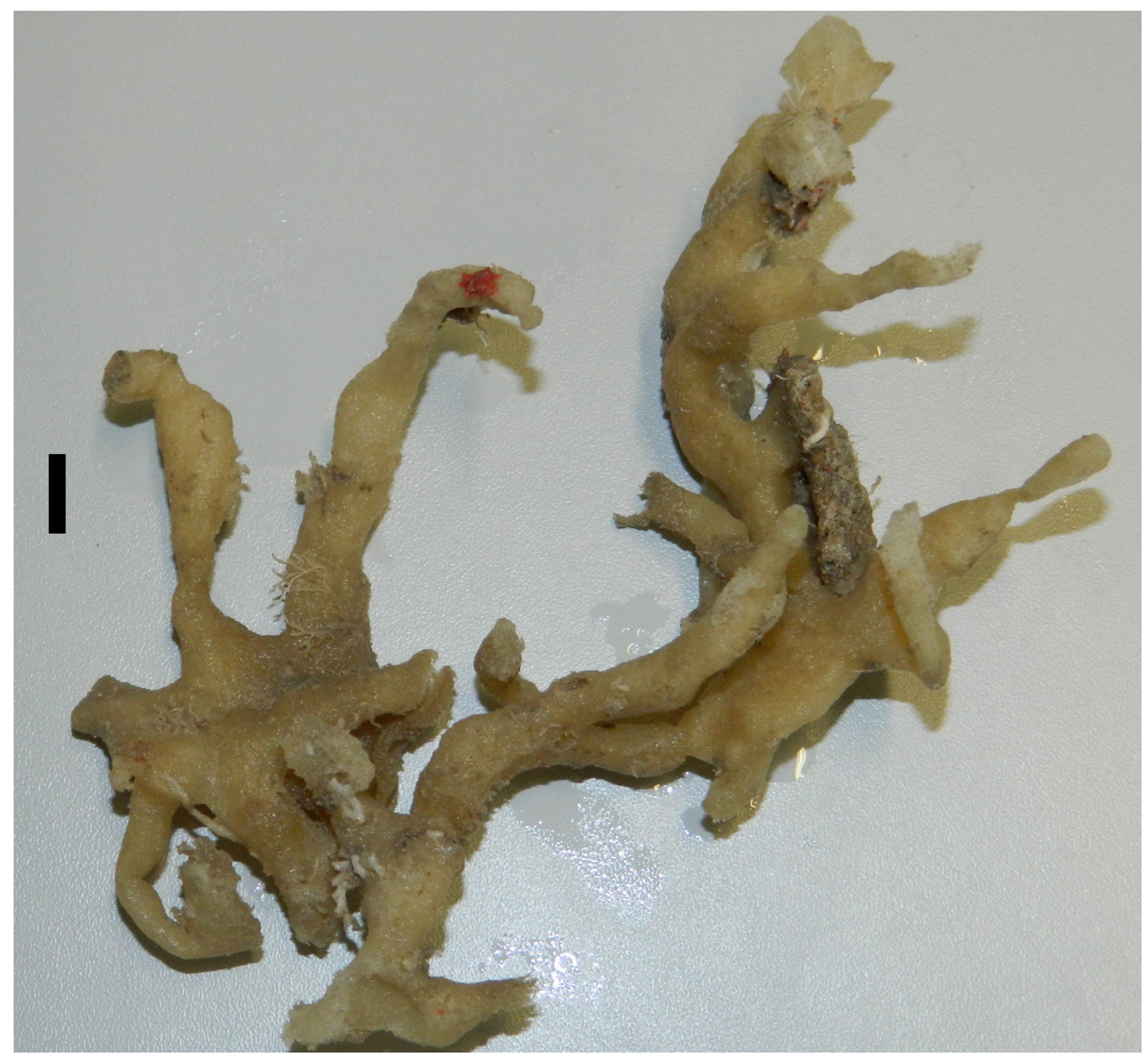

Fig. 7. Haliclona (Flagellia) hamata (Thiele, 1903) subgen. et comb. nov., habitus of ZMA Por. 09285 from Sumba, Indonesia (scale bar $=1 \mathrm{~cm}$ ). 


\section{Remarks}

As discussed above, this species is distinguished primarily by a digitate-arborescent habitus from the very similar but plate-like morphology of $H$. (F.) indonesiae sp. nov. The flagellosigmas of the present species are also subtly larger and thicker than those of the new species; the normal sigmas are distinctly more robust.

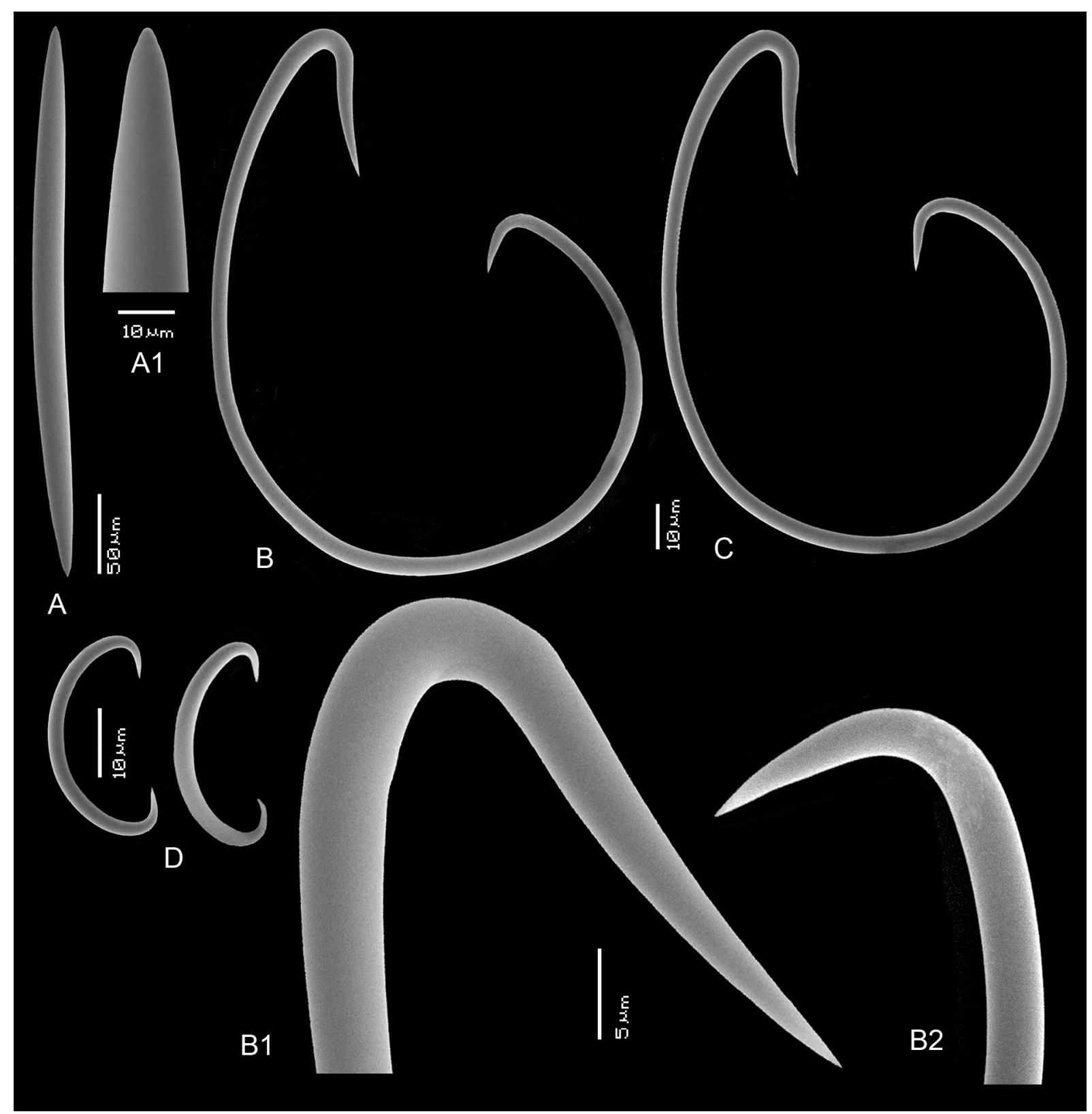

Fig. 8. Haliclona (Flagellia) hamata (Thiele, 1903) subgen. et comb. nov., SEM images of spicules (ZMA Por. 09285). A. Oxea. A. Detail of one of the apices. B-C. Flagellosigmas. B. Detail of long ending of flagellosigma. $\mathbf{B}_{2}$. Detail of short ending of flagellosigma. D. Sigmas. 
Haliclona (Flagellia) hentscheli subgen. et nom. nov.

Fig. 9

Gellius incrustans Hentschel 1912: 390, pl. XV fig. 3, pl. XXI fig. 45.

\section{Etymology}

The specific epithet refers to E. Hentschel, author of Gellius incrustans.

\section{Material examined}

INDONESIA: South Sulawesi, Tana Djampea, Kambarangi Bay, $7.1058^{\circ} \mathrm{S}, 120.6274^{\circ}$ E, depth 0-32 m, trawl, coll. Siboga Expedition stat. 64, 4 May 1899 (ZMA Por. 01225), same data as for previous (ZMA Por. 01226); Maluku, Ambon, Ambon Bay, near Hative Besar, $3.6833^{\circ} \mathrm{N}, 128.1333^{\circ} \mathrm{E}, 0-5 \mathrm{~m}$, snorkeling, coll. R.W.M. Van Soest, Snellius II Expedition stat. 002/II/18A, 6 Sep. 1984 (ZMA Por. 08797); Snellius II Expedition, fieldnr 4.045, NE coast of Sumba, E of Melolo, $9.9033^{\circ} \mathrm{S}, 120.7167^{\circ} \mathrm{E}$, depth $48-57 \mathrm{~m}$, Van Veen grab, 13 Sep. 1984 (unregistered slide); Snellius II Expedition, fieldnr 56J, NE coast of Sumba, E of Melolo, $9.9^{\circ} \mathrm{S}, 120.7477^{\circ} \mathrm{E}$, depth $125 \mathrm{~m}$, dredge, $14 \mathrm{Sep} .1984$ (unregistered slide).

\section{Description}

Encrusting sponges with an uneven surface (Fig. 9A), with slightly raised oscules (Fig. 9A1). One (ZMA 01225, Fig. 9A) encrusts the base of an octocoral. Greyish beige in alcohol. Lateral size up to $2 \times$ $1 \mathrm{~cm}$, thickness $3-4 \mathrm{~mm}$, oscules $2 \mathrm{~mm}$ in diameter. Consistency soft.

SKeLETon. Confusedly Haliclona-like, with paucispicular primary tracts interconnected by single oxeas. Special surface reticulation lacking. No visible spongin.

OXEAS (Fig. 9B-B1). Sharply pointed, straight, in a narrow size range, 198-214-238 × 4-6.4-11.5 $\mu \mathrm{m}$.

Flagellosigmas (Fig. 9C-E). Circular to ovoid in shape, in two size categories. Larger ones (Fig. 9CD) with rather short but distinctly upturned long endings (Fig. 9C1), both large and small ones with gradually widely curved short endings (Fig. 9C2, E). Large flagellosigmas (I), with length of long endings 69-84-98 $\mu \mathrm{m}$, short endings 51-54-63 $\mu \mathrm{m}$, widths 53-66-83 $\mu \mathrm{m}$, thickness $1.5-1.7-2 \mu \mathrm{m}$. Small flagellosigmas (II) (Fig. 9E-F), with length of long endings 27-42-66 $\mu \mathrm{m}$, short endings 16-24$34 \mu \mathrm{m}$, widths $18-29-39 \mu \mathrm{m}$, thickness $0.5-0.8-1.5 \mu \mathrm{m}$.

Normal sigmas (Fig. 9G-H). The most common microscleres, occurring in two distinct size classes, the larger ones (I) (Fig. 9G) with rather sharply bent endings, robust, 57-71-81 $\times 1.5-2.4-3 \mu \mathrm{m}$, the smaller thinner ones (II) (Fig. 9H) incurved more roundedly, 14-22-32 $\times 0.5-0.6-1 \mu \mathrm{m}$.

\section{Distribution and ecology}

Indonesia: Aru Islands, Tana Djampea (island south of Sulawesi), Ambon, Sumba (Marine Ecoregions Arafura Sea, Banda Sea, Lesser Sunda), coral reefs and sand bottoms at 12-125 m depth.

\section{Remarks}

The specimens described here are judged to be conspecific with Gellius incrustans Hentschel, 1912. However, data provided by Hentschel do not entirely match the present specimens: normal sigmas are described as very common, but no size categories were mentioned; only the largest size is quoted as 43$56 \mu \mathrm{m}$, smaller than the present $57-81 \mu \mathrm{m}$. Flagellosigmas are quoted as having a largest 'Durchmesser' of 47-51 $\mu \mathrm{m}$, likewise smaller than in the present specimens. Oxeas were 156-180 $\times 5-6 \mu \mathrm{m}$, according to Hentschel. It remains to be established whether the differences observed here are the result of a less 


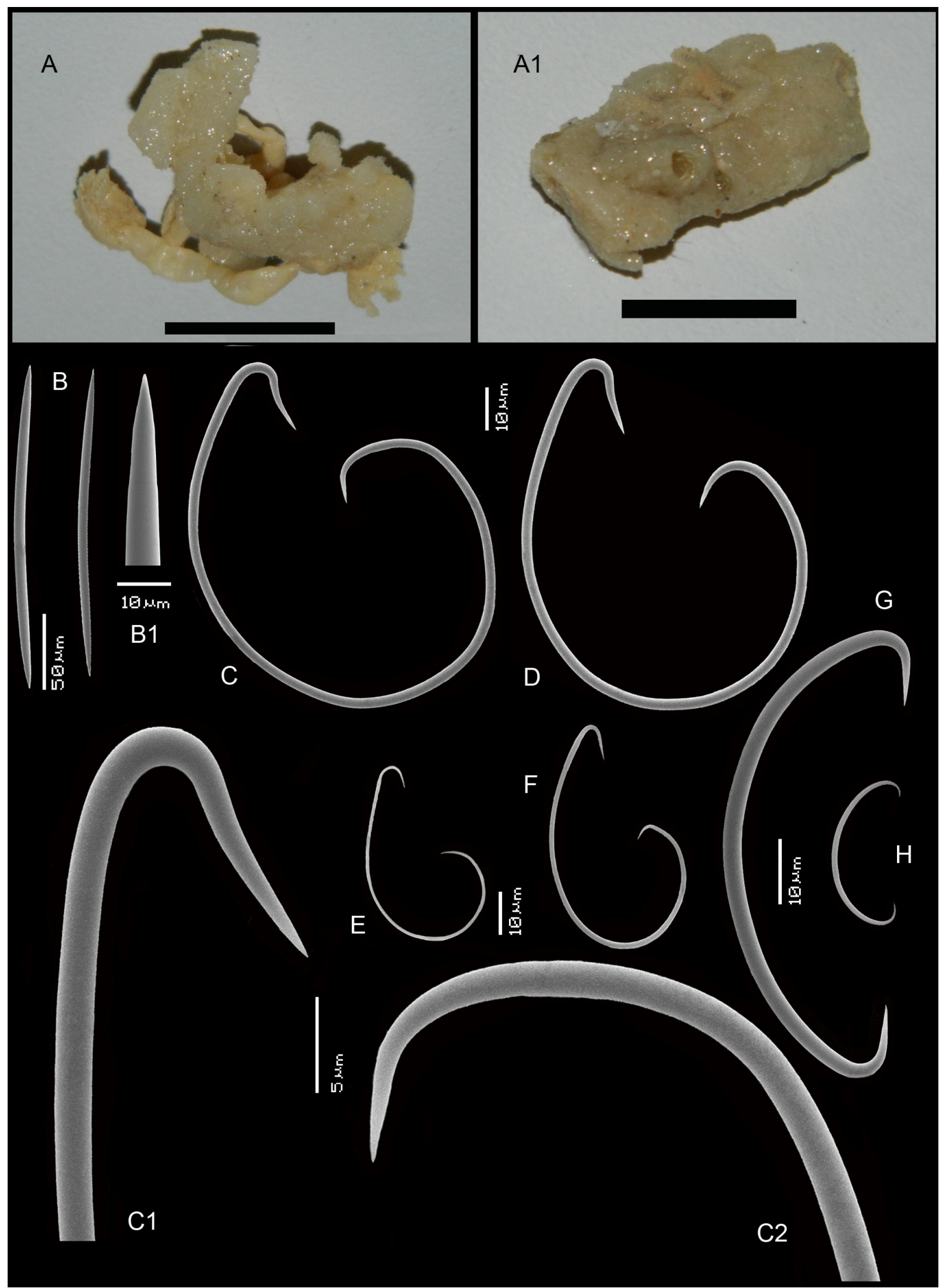

Fig. 9. Haliclona (Flagellia) hentscheli subgen. et nom. nov. A. Habitus of ZMA Por. 01225 from Tana Djampea, Kambarangi Bay, Indonesia (scale bar $=1 \mathrm{~cm}$ ). $\mathbf{A}_{1}$. Habitus of ZMA Por. 01226, from same locality (scale bar $=1 \mathrm{~cm}$ ). B-H. SEM images of spicules (ZMA Por. 01225). B. Oxeas. $\mathbf{B}_{1}$. Detail of one of the apices. C-D. Large category (I) of flagellosigmas. $\mathbf{C}_{1}$. Detail of long ending of large flagellosigma. $\mathbf{C}_{2}$. Detail of short ending of large flagellosigma. E-F. Small flagellosigmas (II). G. Large sigma category (I). H. Small sigma category (II). 
than optimal description by Hentschel, or a genuine difference, in which case the present specimens belong to an undescribed species.

Apart from these differences, transferring Gellius incrustans to the combination Haliclona (Flagellia) incrustans, created a junior secondary homonym of Haliclona foraminosa incrustans (Czerniavsky, 1880) (originally Protoschmidtia foraminosa forma incrustans) and of Haliclona simulans incrustans (Carter, 1887) (Carter 1887: 70, originally Isodictya simulans var. incrustans). Burton (1959b: 220) already solved the latter case of homonymy by giving Carter's subspecies the new name Haliclona carteri Burton, 1959. Here the new combination Haliclona (Flagellia) hentscheli nom. nov. is proposed to solve the homonymy with Czerniavsky's (1880) species, which, in spite of its unrecognizable description remains a senior secondary homonym until such time as its status is resolved. Future reallocation of these species to other valid genera will require reinstatement of Hentschel's and Carter's names.

Burton's (1928) deep-water record of Gellius flagellifer from the nearby Andaman Sea was possibly the present species, as the upper size of the normal sigmas falls within the variation of the above measurements. However, the oxeas of the Andaman specimens are 280-360 $\times 12-14 \mu \mathrm{m}$, well in excess of those measured above. Combined with the deepwater occurrence (300-900 m) the conspecificity appears doubtful.

Haliclona (Flagellia) amirantensis subgen. et sp. nov. urn:1sid:zoobank.org:act:C534BBA1-02C7-4263-88A3-7F2B8E55106E

Fig. 10

Gellius flagellifer Dendy, 1922: 26.

Haliclona flagellifer - Burton 1959b: 218.

Gelliodes flagellifer - Vacelet et al. 1976: 83, Fig. 62.

Sigmadocia flagellifer - Pulitzer-Finali 1993: 327.

non Gellius flagellifer Ridley \& Dendy, 1886: 323; 1887: 42, pl. XIII figs 5,10.

\section{Etymology}

The specific epithet refers to the type locality.

\section{Material examined}

\section{Holotype}

SEYCHELLES: Amirante Islands, $\mathrm{N}$ of Ile Desnoeufs, $6.1333^{\circ} \mathrm{S}, 53.0333^{\circ} \mathrm{E}, 54 \mathrm{~m}$ depth, trawl, coll. R.W.M. Van Soest, IOP-E Expedition stat. 782, field number 783/03, 2 Jan. 1993 (ZMA Por. 12409).

\section{Description}

The sponge (Fig. 10A, circle) forms a central encrustation of approximately $2 \times 2 \times 0.5 \mathrm{~cm}$ on a large Topsentia knoll of $9 \mathrm{~cm}$ high and wide. It has an irregular outline around a $5 \mathrm{~mm}$ diameter oscule. The color of both sponges was noted as beige and the specimen of Haliclona (Flagellia) was only detected by its softer consistency and a less coarse surface.

SKELETon. Confused anisotropic organization with large open spaces, with spicule tracts cored by 1-6 spicules in cross section bound by spongin, but this is not obviously enclosing the tracts. Interconnecting spicules are single oxeas, arranged loosely and irregularly. The surface has a tangential arrangement of single spicules differentiated from the choanosomal reticulation. 


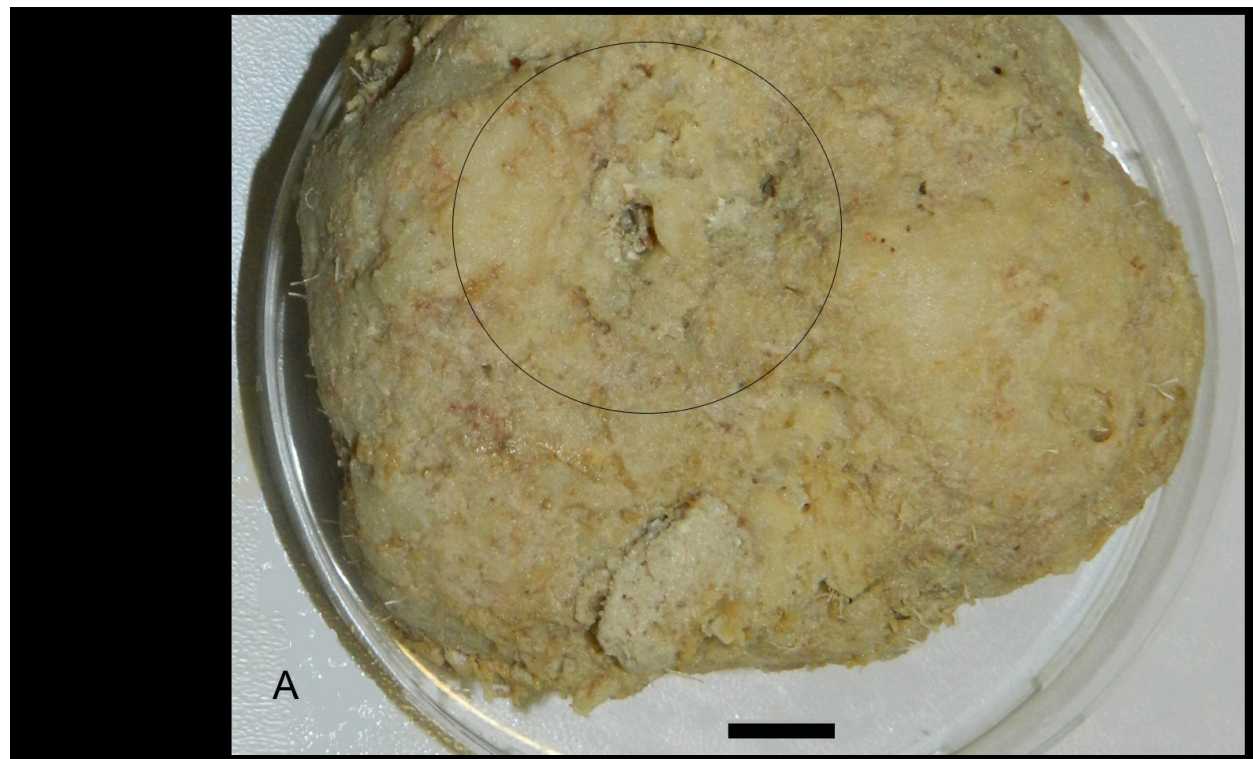

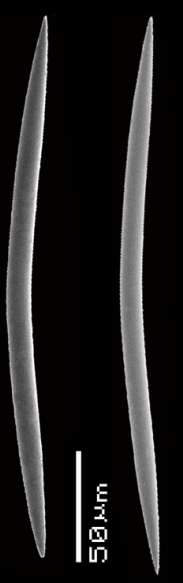

B

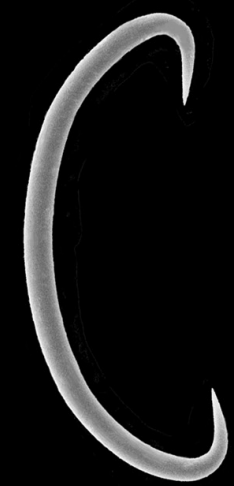

$\mathrm{E}$
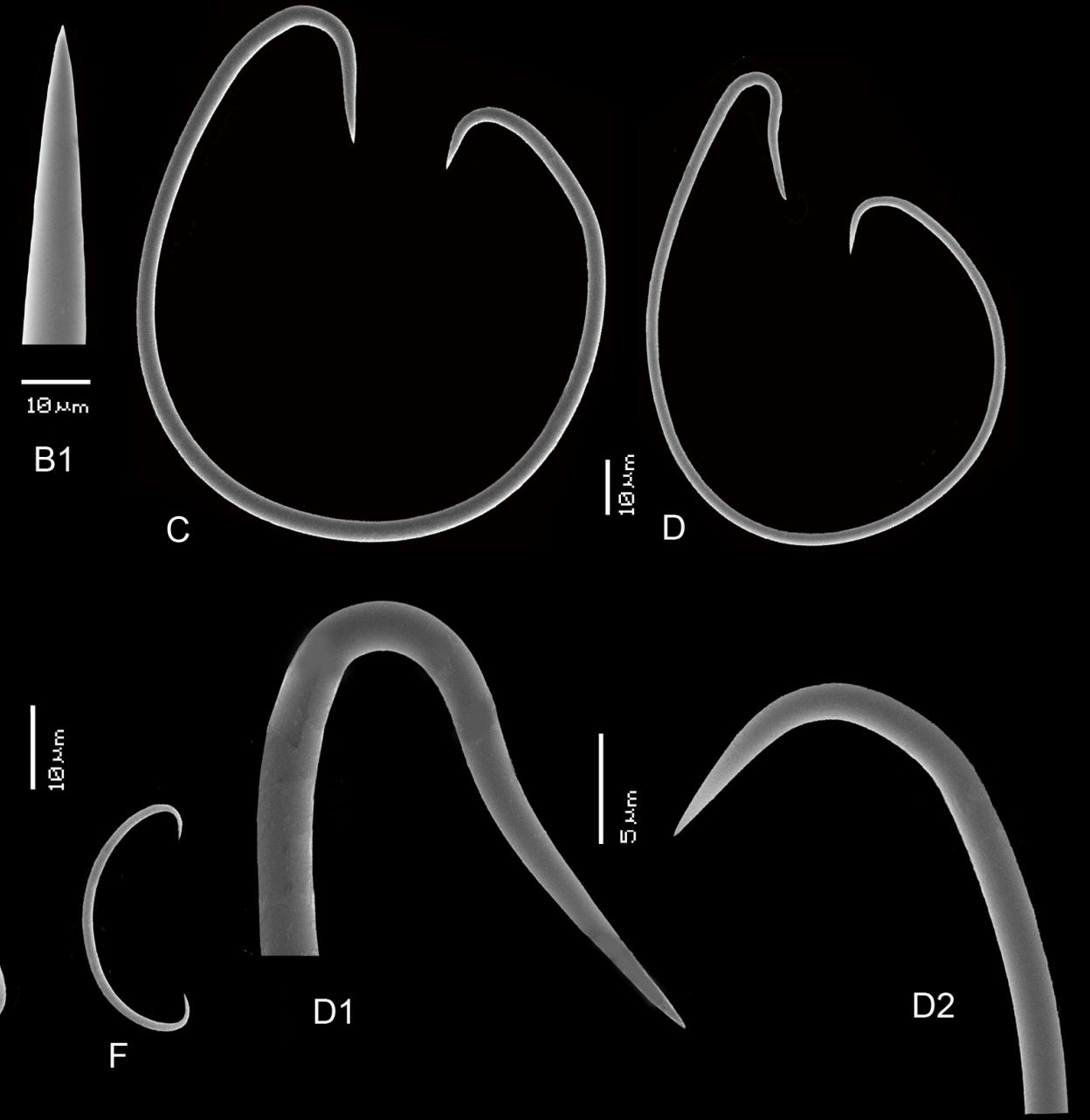

Fig. 10. Haliclona (Flagellia) amirantensis subgen. et sp. nov., holotype (ZMA Por. 12409), from Desnoeufs Island, Amirantes, Seychelles. A. Habitus (encircled) encrusting a large Topsentia specimen $($ scale bar $=1 \mathrm{~cm})$. B-F. SEM images of the spicules. B. Oxeas. $\mathbf{B}_{1}$. Detail of one of the apices. C-D. Flagellosigmas. $\mathbf{D}_{1}$. Detail of long ending of flagellosigma. $\mathbf{D}_{2}$. Detail of short ending of flagellosigma. E. Large sigma category (I). F. Small sigma category (I). 
OXEAS (Fig. 10B-B1). Slightly curved, gradually tapering to sharp points, 207-234-270 × 7.5-9.7$12 \mu \mathrm{m}$.

Flagellosigmas (Fig. 10C-D). Circular to ovoid in shape, with long endings having either an upturned (Fig. 10D1) or straight curvature (Fig. 10C), and with short endings having a rather wide curvature (Fig. 10D2). There is a extensive range of sizes, but no clear division in larger and smaller categories. Long endings 58-106-130 $\mu \mathrm{m}$, short endings 52-77-93 $\mu \mathrm{m}$, width 33-81-108 $\mu \mathrm{m}$, and thickness 1.5$2.4-3.5 \mu \mathrm{m}$.

Normal sigmas (Fig. 10E-F). Two distinct size categories, larger (I) (Fig. 10E), robust, 47-54-63 × 2.5-3.2-3.5 $\mu \mathrm{m}$, and smaller (II) (Fig. 10F), thin, 26-30-33 × 0.5-1.1-1.5 $\mu \mathrm{m}$.

\section{Distribution and ecology}

Seychelles, epizoic on sponge in sandy bottom beyond reefs, $50 \mathrm{~m}$ depth. Also, if synonymy is correct, Madagascar, Kenya, Maldives, and possibly Saya de Malha (Marine Ecoregions Seychelles, East African Coral Coast, Western and Northern Madagascar, Maldives), 37-229 m.

\section{Remarks}

The description by Dendy (1922) of a fairly large encrusting specimen $(5.5 \times 5 \times 1 \mathrm{~cm})$ from Saya de Malha (98 m depth) with the name Gellius flagellifer Ridley \& Dendy, 1886 possibly conforms to the present species. The flagellosigmas were described as having an upturned curve on the long ending and the presence of visible spongin was also noted. However, the sizes of the oxeas were given as $370 \times$ $20 \mu \mathrm{m}$, well in excess of the Seychelles specimen, and no data on sizes of flagellosigmas and normal sigma were provided. This meagre information is not sufficient to be certain of conspecificity.

Burton (1959b) reported Haliclona flagellifer from the Southern Red Sea (26 m) and the Maldives $(229 \mathrm{~m})$. The specimen from the Southern Red Sea had oxeas only $170 \times 10 \mu \mathrm{m}$, clearly smaller than the above measurements. The Maldives data appear closer, with oxeas $320 \times 19 \mu \mathrm{m}$, flagellosigmas $90 \mu \mathrm{m}$, and sigmas $30-60 \mu \mathrm{m}$.

Vacelet et al. (1976) recorded Gellius flagellifer from Southwestern Madagascar (at $37 \mathrm{~m}$ depth, beyond the reefs) and this description matches the above description in most aspects (color, skeleton, sizes and shapes of oxeas and flagellosigmas), except for the normal sigmas, which were given as 30-40 $\times$ $1.2-2 \mu \mathrm{m}$. However, their drawing of these spicules (fig. 62c) shows considerable size variation. There is little doubt that the Madagascar and Amirante material are conspecific.

Pulitzer-Finali (1993) reported Sigmadocia flagellifer from deeper water (117-138 m) off the coast of Kenya. Oxeas were somewhat larger (310-370 × 13-17 $\mu \mathrm{m})$, but flagellosigmas and the larger normal sigmas were similar in size. No mention was made of a smaller sigma category, rendering conspecificity uncertain. However, as the specimen also encrusted a sponge (Asteropus), this material has more similarities than differences.

Haliclona $(F$.$) hentscheli nom. nov. as described above is quite similar to the Seychelles species in$ shape, oxea length, shape of the (large) flagellosigmas and presence of two size categories of normal sigmas. The major difference is the lack of a differentiated small flagellosigma category and the size of the larger normal sigma category, which is clearly smaller (average $54 \mu \mathrm{m}$ ) than that of $H$. (F.) hentscheli nom. nov. (av. $71 \mu \mathrm{m}$ ). Haliclona $(F$.) flagellifera (Ridley \& Dendy, 1886) subgen. et comb. nov. from Marion Island (see below), differs from $H$. (F.) amirantensis subgen. et sp. nov. in the shape of both the larger and smaller flagellosigmas, the presence of upturned long endings in many of the large flagellosigmas, the presence of two normal sigma categories, and the smaller sizes of the oxeas. 
A specimen of $H$. (F.) flagellifera reported from Kerguelen by Boury-Esnault \& Van Beveren (1982) does have flagellosigmas with upturned endings, but is otherwise (oxea sizes, shape of the flagellosigmas, normal sigma sizes) clearly different from $H$. (F.) amirantensis sp. nov. Additional comparisons are given below.

Haliclona (Flagellia) flagellifera (Ridley \& Dendy, 1886) subgen. et comb. nov. Fig. 11

Gellius flagellifer Ridley \& Dendy, 1886: 323.

Gellius flagellifer - Ridley \& Dendy 1887: 42, pl. XIII figs 5, 10.

\section{Material examined}

MARION ISLAND: small dry fragment of holotype, Marine Ecoregion Prince Edward Islands, depth 90-135 m (BMNH 1887.5.2.252).

\section{Description}

Shape (from Ridley \& Dendy 1887): two small, massive encrustations, largest is $2.9 \mathrm{~cm}$ in lateral expansion, $1.6 \mathrm{~cm}$ thick, color pale greyish (in alcohol). A single oscule. Surface shaggy. Consistency soft, brittle.

Skeleton. Haliclona-like, confuse, anisotropic, with primary lines consisting of 1-4 spicules, single spicules interconnecting at all angles, but mostly rectangular, no spongin visible. No special ectosomal arrangement of skeleton and spicules.

OXEAS (Fig. 11A-A1). Slightly curved, fat, cigar-shaped, gradually pointed, 340-389.1-420 × 8-15.1$18 \mu \mathrm{m}$.

Flagellosigmas (Fig. 11B-E). Elongated, elliptical, larger strongly asymmetrical, smaller less so and less elliptical, more ovoid. Curvature of long ending shortly rounded, no upturned hook, curvature of short ending shallow, in a wide size range, suggesting two overlapping size categories but subtly distinguishable by shape. Larger (I) (Fig. 11B-C) with length of long ending 82-96.2-102 $\mu$ m, length of short ending 50-60.6-75 $\mu \mathrm{m}$, width 50-60.2-73 $\mu \mathrm{m}$, thickness 2.5-2.8-3 $\mu \mathrm{m}$. Smaller (II) (Fig. 11DE) with length of long ending 45-54.6-66 $\mu \mathrm{m}$, length of short ending 33-39.8-48 $\mu \mathrm{m}$, width 33-41.5$46 \mu \mathrm{m}$, thickness $1-1.7-2 \mu \mathrm{m}$.

Normal sigmas (Fig. 11F). A single size category, tips slightly incurved, 31-39.6-53 × 1.5-2.2-2.5 $\mu \mathrm{m}$.

\section{Remarks}

Although cosmopolitan distribution is unlikely to occur in sponge species with a depth range limited largely to continental and upper bathyal waters, it is still possible that the present species from an oceanic island could have been capable of covering large distances. Thus, the reported occurrence of $H$. (F.) flagellifera from circumglobal southern ocean localities could be consistent with the occurrence of a single species. Here the literature data from the non-tropical southern ocean records of the species is reviewed. Despite numerous reports (see Remarks below), we consider that the only reliable record of $H$. (F.) flagellifer originates from the type locality at Marion Island (South African administration).

Boury-Esnault \& Van Beveren (1982) reported Gellius flagellifer from Kerguelen Islands at a comparable depth of $195 \mathrm{~m}$. The shape of their specimens was also massive encrustations, up to $4.3 \times 3 \times 0.8 \mathrm{~cm}$. The oxeas were reported as 474-540-589 $\times 13-14-24 \mu \mathrm{m}$, clearly longer than those of the type. The 
flagellosigmas had their longest axis 88-98-129 $\mu \mathrm{m}$ (= length of long ending) and their shorter axis 4556-67 $\mu \mathrm{m}$ (= width), close in measurements to those of the type specimen, but no small flagellosigmas were mentioned. The shape of the flagellosigma in their paper is more narrow-elliptical than in the type, and the long ending has a faint upturned hook. Normal sigmas have a wider range, 40-83-131 $\times 2-5 \mu \mathrm{m}$, and in the illustrations clearly appear to be divisible into two sigma size categories unlike the normal sigmas in the type. Therefore it is uncertain whether the Kerguelen material is conspecific with the type, and for now is considered to belong to an unnamed Haliclona (Flagellia) spec. until the specimen can be examined.

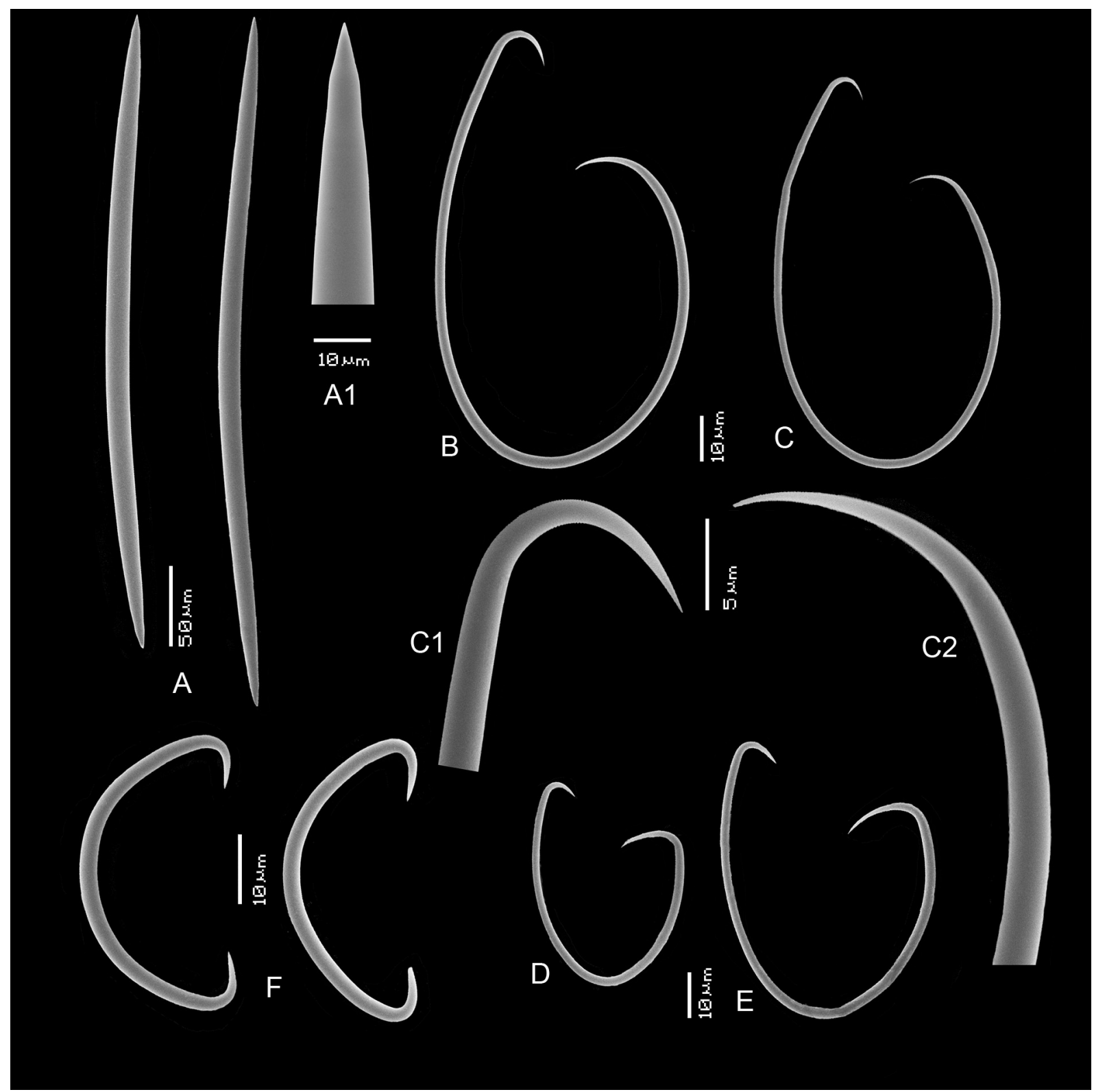

Fig. 11. Haliclona (Flagellia) flagellifera (Ridley \& Dendy, 1886) subgen. et comb. nov., holotype, fragment of BMNH 1887.5.2.252, from Marion Island, South Indian Ocean, SEM images of the spicules. A. Oxea. A $\mathbf{A}_{1}$. Detail of one of the apices. B-C. Large category of flagellosigmas (I). $\mathbf{C}_{1}$. Detail of long ending of large flagellosigma. $\mathbf{C}_{2}$. Detail of short ending of large flagellosigma. D-E. Small flagellosigmas (II). F. Sigmas. 
Burton (1938) reported the species (as Adocia) from Eastern Antarctic Wilkes Land, directly south of Australia, at a depth of $36 \mathrm{~m}$. He provided no data, other than remarking that the flagellosigmas reached $120 \mu \mathrm{m}$ in the longest axis, a similar length to those of the type, but not sufficient to conclude that the Antarctic specimen is conspecific. Göcke \& Janussen (2013) reported this species from the Eastern Weddell Sea, Antarctica, at a depth of $602 \mathrm{~m}$. Oxeas were 570-643-715 $\times 22-26-29 \mu \mathrm{m}$, clearly considerably longer and thicker than the type. Flagellosigmas measured 80-106-140 $\mu \mathrm{m}$ in the longest axis, 60-109-155 $\mu \mathrm{m}$ in the shorter axis, also larger than the type specimen. The normal sigmas were 17-24-31 $\mu \mathrm{m}$, smaller than in the type. Although generally similar to the type, the spicule size data and the lack of differentiated larger and smaller flagellosigmas indicates a likely specific difference.

It is not possible to judge whether specimens reported by Pansini \& Sarà (1999) from Magellan Strait are similar to the type specimen, because no description was provided.

Dendy (1924) and Bergquist \& Warne (1980) reported specimens from northern New Zealand waters (Three Kings Islands), at depths of $200 \mathrm{~m}$ and $60-120 \mathrm{~m}$, respectively. The specimens differed in the size of the oxeas, with Dendy's specimen possessing oxeas of only $210 \times 8 \mu \mathrm{m}$, while those of Bergquist $\&$ Warne were close to those of the type in size, $460 \times 15 \mu \mathrm{m}$. Both specimens had small flagellosigmas of 46 and $64 \mu \mathrm{m}$ respectively, and a single size of normal sigmas (20 and $28 \mu \mathrm{m}$ respectively). Neither specimen appears very close to the type morphologically.

Uriz (1987, 1988) described Gellius flagellifer from Namibia, SE Atlantic (at depths of 183-290 m). The oxeas were given as 420-570 $\times 16-30 \mu \mathrm{m}$, much larger than the type. In addition, the flagellosigmas and normal sigmas were larger, suggesting that the Namibian material could be specifically different.

Samaai \& Gibbons' (2005) description of Haliclona (Gellius) flagellifer from the Atlantic coast of South Africa $(15 \mathrm{~m})$ differs from Uriz' material and from the type of $H$. (F.) flagellifera in having two size classes of normal sigmas, $73-91 \mu \mathrm{m}$ and $25 \mu \mathrm{m}$.

These comparisons lead to the conclusion that Haliclona (Flagellia) flagellifera is so far endemic to Marion Island of the Prince Edward Islands archipelago in the Southern Indian Ocean. Specimens reported as Haliclona (Gellius) flagellifera from other ocean basins are regarded as likely different species.

Haliclona (Flagellia) porosa (Fristedt, 1887) subgen. et comb. nov.

Figs $12-13$

Desmacella porosa Fristedt, 1887: 440, pl. 24 figs 36-37, pl. 28 fig. 15.

Gellius vagabundus Vosmaer, 1885: 29, only the var. $\gamma$, pl. V figs 36-38.

?Gellius rhaphidiophorus Brøndsted, 1933: 18, fig. 7.

Gellius porosus - Lundbeck 1902: 73, pl. XIV fig. 2. — Lundbeck 1909: 434. — Hentschel 1916: 11. —

Ferrer Hernandez 1918: 22, fig. 3. — Ferrer Hernandez 1923: 16. — Rezvoi 1924: 243. — Rezvoi

1928: 91. — Hentschel 1929: 978. — Koltun 1959: 213.

Haliclona porosus - Koltun 1962: 186. — Hoshino 1987: 38.

Gellius flagellifer - Lambe, 1896: 185, pl. I fig. 4. — Topsent 1896: 281, pl. VIII fig. 4.

Hemigellius sp. aff. flagellifer - De Weerdt \& Van Soest 1987: 315.

non Gellius flagellifer sensu Koltun 1959: 212 (= Haliclona (Gellius) sp.); nec: Hemigellius sp. aff. flagellifer sensu Ginn et al. 1998: 1099 (= Haliclona (Gellius) sp.) 


\section{Material examined}

BARENTS SEA: slide only (Fig. 12A-F), Willem Barents Expedition, ?1880, depth uncertain, between 212 and 297 m (ZMA Por. 20742).

MAURITANIA: off Banc d'Arguin, 114 m depth, Van Veen grab, coll. R.W.M. Van Soest, Mauritania II Exped. stat. 033, 9 Aug. 1988 (ZMA Por. 06624) (Fig. 13A-F).

\section{Description}

Because of the substantial difference between the two localities, each specimen is described separately.

ZMA 20742 (Fig. 12A-F) is a slide only, made from a dried fragment apparently no longer present in the collection.

ZMA 06624 (Fig. 13A) is a small encrustation of $5 \times 5 \times 2 \mathrm{~mm}$ on dead Lophelia corals, surface optically smooth. Consistency soft.

SKELETON. Specimen 20742 (Fig. 12A): the surface has confused tangentially arranged single spicules. The choanosomal skeleton has paucispicular ascending tracts interconnected irregularly by single spicules. Microscleres, especially normal sigmas, are relatively rare throughout the skeleton. Specimen 06642: no recognizable surface skeleton. The choanosomal skeleton is irregular, anisotropic with paucispicular

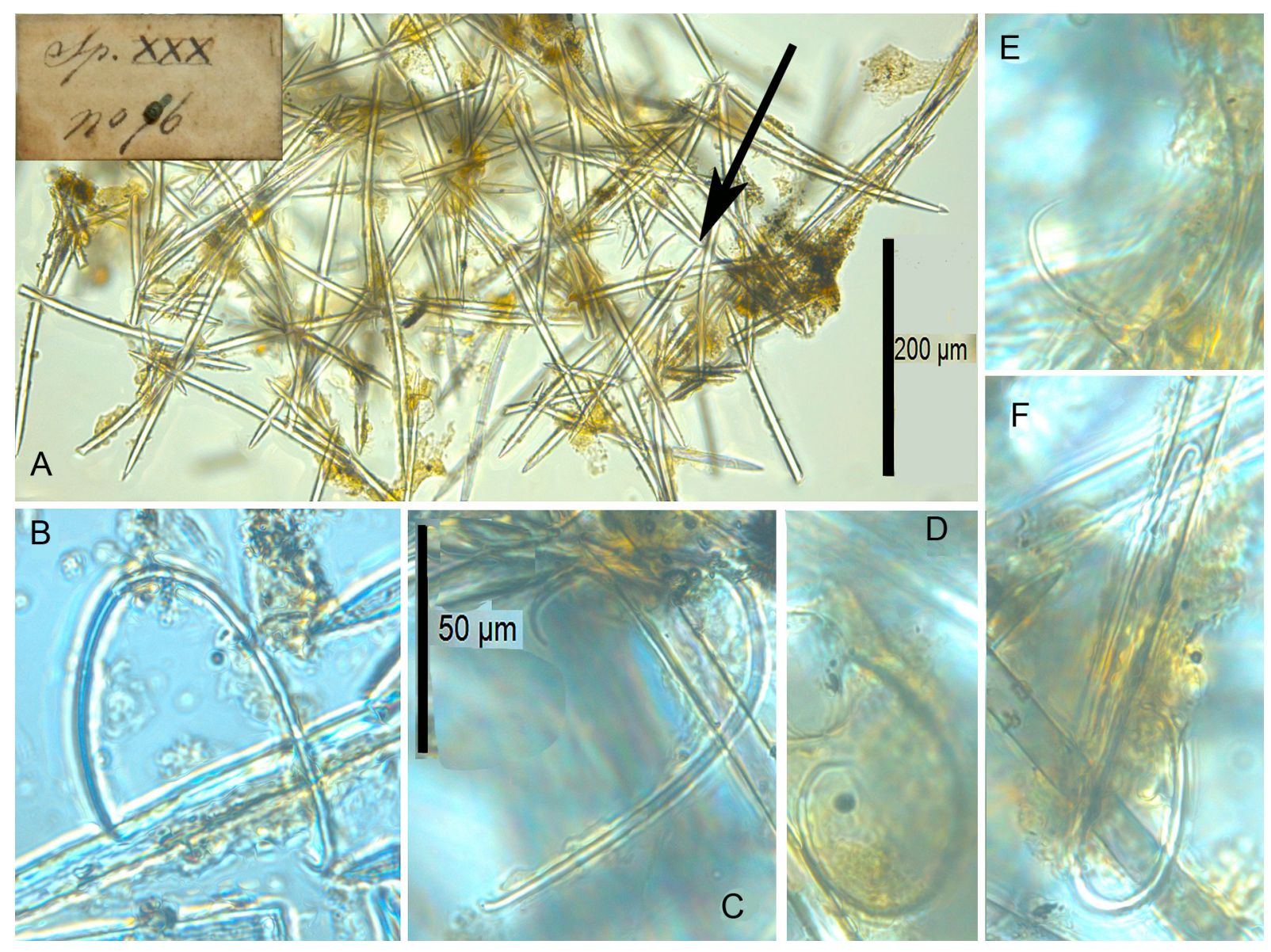

Fig. 12. Haliclona (Flagellia) porosa (Fristedt, 1887) subgen. et comb. nov., from Vosmaer's (1885) Barents Sea collection, light microscopic images made from slide of ZMA Por. 20742 A. Skeleton of the surface with flagellosigma (arrow). B-F. Flagellosigmas (all photographed at same scale). 
ascending tracts and single connecting spicules. Microscleres, especially the normal sigmas, are rare throughout the choanosome.

OXEAS. Straight or slightly curved, elongately cigar-shaped. ZMA 20742 (Fig. 12A): 243-271-297 × 8-9.7-12 $\mu \mathrm{m}$. ZMA 06624 (Fig. 13B, B1): 267-307-333 × 8.5-11.2-13 $\mu \mathrm{m}$.

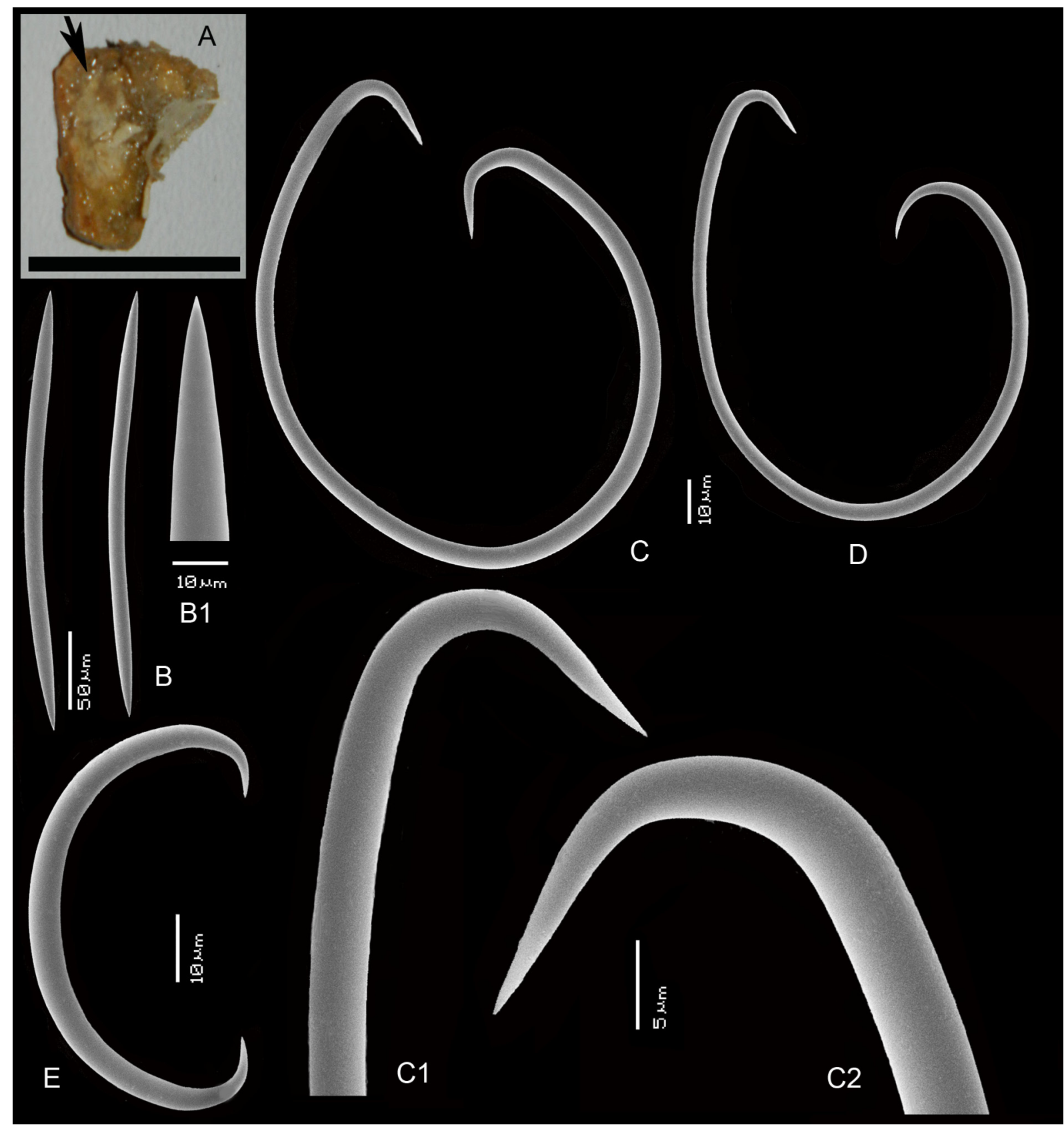

Fig. 13. Haliclona (Flagellia) porosa (Fristedt, 1887) subgen. et comb. nov., from Mauritania (ZMA Por. 06624). A. Habitus (arrow) on dead coral (scale bar $=1 \mathrm{~cm}$ ). B-E. SEM images of the spicules. B. Oxeas. $\mathbf{B}_{1}$. Detail of one of the apices. C-D. Flagellosigmas. $\mathbf{C}_{\mathbf{1}}$. Detail of long ending of flagellosigma. $\mathbf{C}_{2}$. Detail of short ending of flagellosigma. E. Sigma. 
Flagellosigmas. ZMA 20742 (Fig. 12B-F): elliptical to ovoid, in a large size range, but not divisible into two categories, length of long ending 48-82-108 $\mu \mathrm{m}$, of short ending 27-47-59 $\mu \mathrm{m}$, width 32 46-57 $\mu \mathrm{m}$, thickness 1-1.8-3 $\mu \mathrm{m}$. ZMA 06624 (Fig. 13C, C1, C2, D): predominantly ovoid or circular, larger than those of 20742, also in a large size range, not divisible. Long endings have straight curvature, length of long endings $57-109-156 \mu \mathrm{m}$, short endings 43-79-106 $\mu \mathrm{m}$, width 42-83-117 $\mu \mathrm{m}$, thickness $1.5-3.3-5 \mu \mathrm{m}$.

Normal sigmas. Rare, in both. ZMA 20742: 45-48 × 2-2.5 $\mu \mathrm{m}$ (n=3). ZMA 06624 (Fig. 13E): 40-51$61 \times 2-4.0-5 \mu \mathrm{m}(\mathrm{n}=9)$.

\section{Distribution and ecology}

Arctic waters, NW Pacific, Gulf of Biscay, Gulf of Saint Lawrence, off Mauritania (Marine Ecoregions West Greenland Shelf, East Greenland Shelf, North and East Barents Sea, South European Atlantic Shelf, Gulf of Saint Lawrence, Sahelian Upwelling). Depth occurrence 90-400 m.

\section{Remarks}

All slides and specimens in the ZMA and RMNH collections labeled as Gellius vagabundus remaining from the material studied by Vosmaer (1885), including several labeled as the var. $\gamma$, and even one specimen (nr. 74) indicated by Vosmaer (1885: 29, pl. V figs 38-38) as having the spiculation depicted, were examined. No flagellosigmas were found, all specimens and fragments belonged either to Desmacella, Hymeniacidon or Hemigellius, with sigmas of normal shape, or lacking. There is one dried sample without identification in the ZMA collection, bearing only a small label with text 'Sp. XXX No. 76', the number given to Gellius vagabundus by Vosmaer (1885). The sample consists of three fragments, all of which are Hymeniacidon-like (with larger and smaller styles, as depicted in pl. V figs 32-33). However, the ZMA 20742 slide presumably made from the dried material does have the spicules depicted in Vosmaer's Pl. V figs 36-38. Although the number is 76, not 74, it is clear that this slide was made from a previously present dried fragment and is now is all that remains of Vosmaer's var. $\gamma$.

Both the Barents Sea slide and the Mauritanian specimen have been assigned to $H$. $(F$.) porosa based on spicule shapes, and the presence of a single category of normal sigmas that are characteristically rare. They resemble Fristedt's description of Desmacella porosa from Davis Strait, although the type specimen - listed to be present as Gellius porosus in the Zoologisk Museum Copenhagen under reg. nr. DEM 107 - was much larger $(9 \times 6 \mathrm{~cm})$. The size of the oxeas was given by Fristedt as $350 \mu \mathrm{m}$, but Lundbeck (1902) re-examined the type and found some of them to be as small as $250 \mu \mathrm{m}$. Fristedt did not mention any normal sigmas, but Lundbeck (1902) found several normal sigmas. The length of the flagellosigmas was given by Fristedt as $120 \mu \mathrm{m}$ across, somewhat larger than the ones of ZMA 20742, but smaller than those of ZMA 06624. Lundbeck (1902), in his description of a specimen from the $\mathrm{N}$ coast of Iceland, found oxeas and flagellosigmas in the same size range as those of the above described Barents Sea slide (ZMA Por. 20742), and the normal sigmas were 50-80 $\mu \mathrm{m}$, somewhat larger than those of the present material.

Topsent (1896: 281, pl. VIII fig. 4) reported Gellius flagellifer from the nearby Gulf of Biscaye (depth $400 \mathrm{~m}$ ), with oxeas $350 \times 13-14 \mu \mathrm{m}$ and flagellosigmas up to 90-100 $\times 2 \mu \mathrm{m}$. The drawing of the flagellosigmas closely resembles the present material. He neither discussed, nor figured the normal sigmas, suggesting that they were rare [he admitted to their presence later (Topsent 1904)]. The rarity of the normal sigmas makes it likely that the material belongs to $H$. (F.) porosa. Lambe's (1896) record of Gellius flagellifer is probably also $H$. $(F$.) porosa for the same reasons. 
Ferrer Hernandez (1918: 22, fig. 3) reported Gellius porosus from the coast of Asturias, N Spain, at $200 \mathrm{~m}$ depth (material originally collected by Orueta). His description and figure may be similar to the type of Fristedt.

In addition to $H$. (F.) porosa, Lundbeck (as well as other authors, e.g., Rezvoi 1928: 91) also described Arctic specimens assigned to Gellius flagellifer Ridley \& Dendy, 1886. Lundbeck's specimens differ from his $H$. (F.) porosa in having larger oxeas (up to $476 \mu \mathrm{m}$ long), and abundant normal sigmas in a large size range. For these and other reasons, it is unlikely that these Arctic specimens are conspecific with specimens occurring in the Southern Ocean Prince Edward Archipelago. There are subtle small differences in the sizes and shapes of the flagellosigmas and the normal sigmas when compared with the type of $H$. (F.) flagellifera (see above). As Lundbeck insisted that these specimens were not conspecific with $H$. (F.) porosa (several authors, e.g., Topsent 1896 and Lambe 1896 thought otherwise), and access to the specimens was not possible, they remain provisionally as Haliclona $(F$.) spec. until their status as a separate species from $H$. (F.) porosa can be established (but see also below).

Brøndsted's (1933) species Gellius rhaphidiophorus from Greenland at $410 \mathrm{~m}$ depth, was described as close to Gellius porosus, with "more or less flagelliform" sigmas of 71-110 $\mu \mathrm{m}$, in addition to rather rare sigmas of 20-36 $\mu \mathrm{m}$ and raphides of 36-40 $\mu \mathrm{m}$. Species with flagellosigmas and raphides are otherwise not known, so possibly the raphides are foreign, in which case it could be a junior synonym of $H$. (F.) porosa. However, conspecificity is uncertain because the presence of true flagellosigmas cannot be verified due to the lack of illustrations and the ambiguous description. Likewise, many records of Gellius porosus and Sigmadocia porosa (cf. above in the historical overview) remain to be substantiated, as they were either not taxonomically described or insufficiently characterized.

As mentioned above, Koltun (1959: 213) and Ginn et al. (1998: 1099) erroneously reported Gellius or Hemigellius flagellifer from Arctic and East Canadian waters, based on misidentification of their specimens.

The name combination Haliclona $(F$.) porosa is threatened by previous use of the name 'porosa' in combination with the unaccepted genus name Arcesios and the subgenus name Reniera. Arcesios porosa Duchassaing \& Michelotti, 1864 is described unrecognizably and no original material is known to be extant in collections (cf. Van Soest et al. 1983). Schmidt (1870: 40) assigned this species to Reniera Schmidt, 1862, claiming in a two-line comment that Arcesios was a junior synonym of Reniera, but failed to provide any evidence. Schmidt stated he had a specimen from "Crabb Island" [sic] that answered to the descriptions of A. porosa. He gave no description of this material and no specimen from "Crabb Island" is kept in the collections of the Museum of Comparative Zoology, Harvard, or the Musée de Zoologie at Strasbourg, where most of Schmidt's 1870 material is housed. Although Reniera is a subgenus of Haliclona, there is no evidence that Arcesios porosa is a member of the subgenus. This fact precludes a definite and formal decision about the preoccupied state of the combination Haliclona (Flagellia) porosa and does not warrant proposal of a new name for it as a junior secondary homonym.

An additional homonym of the present combination is Reniera cinerea var. porosa Topsent, 1901. This was renamed Reniera topsenti Thiele, 1905 because of Schmidt's (1870) combination Reniera porosa (and was subsequently assigned to the genus Haliclona as H. topsenti by Burton (1940: 99). Because Schmidt's combination has priority, even if it is likely not the same species as Arcesios porosa, the name Reniera topsenti and the current combination Haliclona topsenti remain accepted. 
Haliclona (Flagellia) hiberniae subgen. et sp. nov. urn:1sid:zoobank.org:act:EAB80C5A-6259-4189-90D9-1715A83A3A2A

Fig. 14

Gellius flagellifer - Topsent 1904: 231, in part (only stat. 584). — Stephens 1916: 233; 1917: 5; 1921: 6. Haliclona (Gellius) flagellifera - Van Soest et al. 2007: 131.

non Gellius flagellifer Ridley \& Dendy 1886: 323; 1887: 42, pl. XIII figs 5, 10.

\section{Etymology}

'Hibernia' is the Latin name of Ireland in Roman times, chosen here as a reference to the type locality.

\section{Material examined}

\section{Holotype}

NORTH ATLANTIC: SE Rockall Bank, W of Ireland, $55.4994^{\circ} \mathrm{N}, 15.8007^{\circ} \mathrm{W}$, depth $560 \mathrm{~m}$, boxcore, coll. R.W.M. Van Soest, BIOSYS2005 stat. BX66, 1 Jul. 2005 (ZMA Por. 19596a).

\section{Paratype}

NORTH ATLANTIC: SE Rockall Bank, W of Ireland, $55.4444^{\circ} \mathrm{N}, 16.0756^{\circ} \mathrm{W}$, depth $762 \mathrm{~m}$, boxcore, coll. R.W.M. Van Soest, BIOSYS2005 stat. BX72, 4 Jul. 2005 (ZMA Por. 19619).

\section{Additional specimens examined}

NORTH ATLANTIC: SE Rockall Bank, W of Ireland, $55.4991^{\circ} \mathrm{N}, 15.7967^{\circ} \mathrm{W}$, depth $626 \mathrm{~m}$, boxcore, coll. R.W.M. Van Soest, Moundforce 2004 stat. BX32, 2 Sep. 2004 (ZMA Por. 18506, 18527d); SE Rockall Bank, W of Ireland, $55.5037^{\circ} \mathrm{N}, 15.7852^{\circ} \mathrm{W}$, depth $673 \mathrm{~m}$, boxcore, coll. R.W.M. Van Soest, Moundforce 2004 stat. BX33, 2 Sep. 2004 (ZMA Por. 18536a); SE Rockall Bank, W of Ireland, $55.4359^{\circ} \mathrm{N}, 16.1158^{\circ} \mathrm{W}$, depth $778 \mathrm{~m}$, boxcore, coll. R.W.M. Van Soest, Moundforce 2004 stat. BX41B, 5 Sep. 2004 (ZMA Por. 18551); SE Rockall Bank, W of Ireland, $55.4998^{\circ} \mathrm{N}, 15.7982^{\circ} \mathrm{W}$, depth $602 \mathrm{~m}$, boxcore, coll. R.W.M. Van Soest, BIOSYS2005 stat. BX10, 10 Jul. 2005 (ZMA Por. 19407, 19412); SE Rockall Bank, W of Ireland, 55.4993 ${ }^{\circ}$ N, $15.7979^{\circ} \mathrm{W}$, depth $587 \mathrm{~m}$, boxcore, coll. R.W.M. Van Soest, BIOSYS2005 stat. BX12, 25 Jun. 2005 (ZMA Por. 19421); SE Rockall Bank, W of Ireland, $55.5037^{\circ} \mathrm{N}, 15.7869^{\circ} \mathrm{W}$, depth $614 \mathrm{~m}$, boxcore, coll. R.W.M. Van Soest, BIOSYS2005 stat. BX28, 27 Jun. 2005 (ZMA Por. 19476a); SE Rockall Bank, W of Ireland, 55.4440 ${ }^{\circ} \mathrm{N}, 16.0752^{\circ} \mathrm{W}$, depth 785 m, boxcore, coll. R.W.M. Van Soest, BIOSYS2005 stat. BX38, 28 Jun. 2005 (ZMA Por. 19517); SE Rockall Bank, W of Ireland, 55.5011 ${ }^{\circ}$ N, $15.7887^{\circ} \mathrm{W}$, depth 577 m, boxcore, coll. R.W.M. Van Soest, BIOSYS2005 stat. BX96, 6 Jul. 2005 (ZMA Por. 19690); SE Rockall Bank, W of Ireland, 55.4429 N, 16.0974 W, depth $644 \mathrm{~m}$, boxcore, coll. R.W.M. Van Soest, BIOSYS2005 stat. BX115, 9 Jul. 2005 (ZMA Por. 19745, 19752); SE Rockall Bank, W of Ireland, 55.4907 N, $15.8013^{\circ} \mathrm{W}$, depth $573 \mathrm{~m}$, boxcore, coll. R.W.M. Van Soest, BIOSYS2005 stat. BX153, 11 Jul. 2005 (ZMA Por. 19985); SE Rockall Bank, $\mathrm{W}$ of Ireland, $55.5012^{\circ} \mathrm{N}, 15.7885^{\circ} \mathrm{W}$, depth $585 \mathrm{~m}$, boxcore, coll. R.W.M. Van Soest, BIOSYS2005 stat. BX160, 11 Jul. 2005 (ZMA Por. 20023); Porcupine Bank, W of Ireland, 53.77 ${ }^{\circ} \mathrm{N}, 13.9472^{\circ} \mathrm{W}$, depth 683-749 m, dredge, coll. R.W.M. Van Soest, HERMES2005 stat. DR190, 14 Jul. 2005 (ZMA Por. 20099); Porcupine Bank, W of Ireland, 53.7701 ${ }^{\circ} \mathrm{N}, 13.9457^{\circ} \mathrm{W}$, depth 745-754 m, dredge, coll. R.W.M. Van Soest, HERMES2005 stat. DR215, 17 Jul. 2005 (ZMA Por. 20123).

\section{Unregistered slides examined}

NORTH ATLANTIC: W of Ireland, SE Rockall Bank, $55.5007^{\circ} \mathrm{N}, 15.7893^{\circ} \mathrm{W}$, depth $586 \mathrm{~m}$, boxcore, coll. R.W.M. Van Soest, BIOSYS2005 stat. BX71, 4 Jul. 2005; W of Ireland, SE Rockall Bank, $55.4441^{\circ} \mathrm{N}, 16.0756^{\circ} \mathrm{W}$, depth 767 m, boxcore, coll. R.W.M. Van Soest, BIOSYS2005 stat. BX78, 


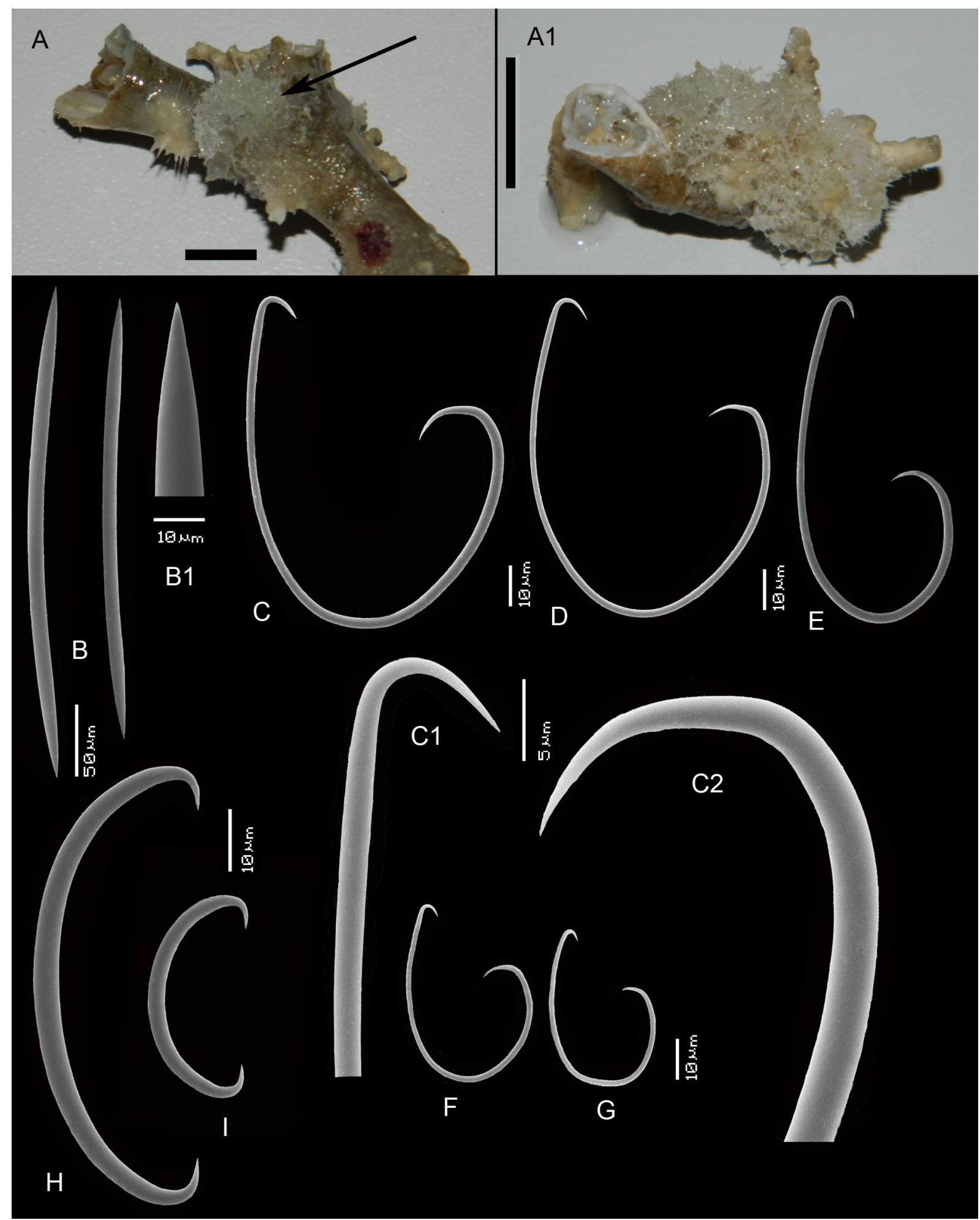

Fig. 14. Haliclona (Flagellia) hiberniae subgen. et sp. nov., from the deep water of the Rockall Bank, W of Ireland. A. Habitus (arrow) of holotype (ZMA Por. 19596a), encrusting a dead coral. A. Habitus (paratype ZMA Por. 19619), encrusting a hydrocoral. B-I. SEM images of the spicules. B. Oxeas. $\mathbf{B}_{1}$. Detail of one of the apices. $\mathbf{C}-\mathbf{E}$. Large category of flagellosigmas (I). $\mathbf{C}_{\mathbf{1}}$. Detail of long ending of large flagellosigma. $\mathbf{C}_{2}$. Detail of short ending of large flagellosigma. F-G. Small category of flagellosigmas (II). H. Large category of sigmas (I). I. Small category of sigmas (II). 
4 Jul. 2005; W of Ireland, SE Rockall Bank, 55.4428 ${ }^{\circ} \mathrm{N}, 16.0975^{\circ} \mathrm{W}$, depth $644 \mathrm{~m}$, boxcore, coll. R.W.M. Van Soest, BIOSYS2005 stat. BX114, 9 Jul. 2005; W of Ireland, SE Rockall Bank, $55.5011^{\circ}$ N, $15.7884^{\circ}$ W, depth 585 m, boxcore, coll. R.W.M. Van Soest, BIOSYS2005 stat. BX161, 11 Jul. 2005; W of Ireland, SE Rockall Bank, 55.4443 ${ }^{\circ}$ N, $16.0756^{\circ}$ W, depth 691 m, boxcore, coll. R.W.M. Van Soest, BIOSYS2005 stat. BX168, 12 Jul. 2005.

\section{Description}

Small dirty white to greyish brown or greyish beige encrustations (Fig. 14A holotype, A1 paratype), often forming thick cushions or small globular masses, occasionally pear-shaped (grey in alcohol). Color remains unchanged in alcohol. Size variable from tiny, $<2 \mathrm{~mm}$ individuals up to $2.5 \times 1.6 \times 1 \mathrm{~cm}$. Surface undulating to shaggy, sometimes 'hairy' due to protruding spicule tracts, and also appearing clathrate. There may be one or two oscules, only apparent in larger, thicker specimens. Consistency soft.

Skeleton. Confused reticulation, consisting of ascending paucispicular spicule tracts connected by single spicules, spongin present only at the nodes.

OXEAS (Fig. 14B-B1). Slightly curved to almost straight, 288-367-419 ×6-11.1-14 $\mu \mathrm{m}$.

Flagellosigmas (Fig. 14C-G). Similar to those of Haliclona (Flagellia) flagellifera, ovoid, larger spicules strongly asymmetrical, smaller less so, curvature of long ending shortly rounded (Fig. 14C1), no upturned hook, curvature of short ending shallow (Fig. 14C2). Found in a wide size range, suggesting two overlapping size categories, but this depends on individual sponges. Larger spicules (I) (Fig. 14CE) with length of long ending 64-104-159 $\mu \mathrm{m}$, length of short ending 48-69-106 $\mu \mathrm{m}$, width 51-73$102 \mu \mathrm{m}$, thickness 1.5-2.6-4 $\mu \mathrm{m}$. Smaller (II) (Fig. 14F-G), length of long ending 13-29.5-55 $\mu \mathrm{m}$, length of short ending 10-27-39 $\mu \mathrm{m}$, width $12-27-45 \mu \mathrm{m}$, thickness $0.5-1.05-2 \mu \mathrm{m}$.

NoRmal sigmas (Fig. 14H-I). Numerous, in two distinct size categories, larger (I) (Fig. 14H) robust, with more shallow curve, 53-76-92 × 2.5-3.3-5 $\mu \mathrm{m}$, smaller (II) (Fig. 14I) thin, deeper curve, with more distinct incurved endings, $28-33.5-39 \times 1-1.6-2.5 \mu \mathrm{m}$.

\section{Distribution and ecology}

Rockall and Porcupine Banks, W of Ireland (Marine Ecoregion Celtic Seas). Known predominantly from deep-water coral banks. Depth range: 560-785 m (Stephens (1921) mentions 90-1328 m).

\section{Remarks}

The present deep-water North Atlantic specimens are overall very similar to the type of Gellius flagellifer. The one major difference is the occurrence of two distinct size categories of normal sigmas. Minor differences are thinner oxeas and larger size range of the two flagellosigmas' size categories in the present specimens.

Topsent (1904) reported Gellius flagellifer from the Azores $(845-1360 \mathrm{~m})$. Oxea size ranges were from 335-345 $\times 8-10 \mu \mathrm{m}$ in the more shallow station, to $620-680 \times 18-20 \mu \mathrm{m}$ at the deeper stations, suggesting a relationship between oxea size and depth. In the Azores material flagellosigmas reached sizes of up to $118 \mu \mathrm{m}$, and normal sigmas occurred in a large size range of $30-80 \mu \mathrm{m}$, suggesting the presence of size categories in both. It is possible that the Azores specimens conform to the Irish material, at least the shallower sample (but there is some doubt over the identity of the deeper sample, see below).

Conspecificity is also likely for Irish material reported by Stephens (1921). She described specimens from the Porcupine Bank (698-1145 m depth) with oxeas up to $400 \times 13 \mu \mathrm{m}$, flagellosigmas of up to $120 \mu \mathrm{m}$ (width 60-90 $\mu \mathrm{m}$ ), and sigmas in a large size range of 35-90 $\mu \mathrm{m}$. 
Remarkably, Topsent (1928: 314) took the erroneous view that his earlier reports on Gellius flagellifer were part of what he considered to be Gellius vagabundus (Schmidt, 1870), referring to Vosmaer as the inspiration for this change. In fact, Topsent's (1928) description of 'Gellius vagabundus' from $1378 \mathrm{~m}$ near São Miguel, Azores, is likely to be a different species from his other described specimens as the sigmas appear dissimilar to the flagellosigmas discussed here. Possibly, it is a Haliclona (Gellius) species, but it is not the present species.

Lundbeck (1902) (and other authors such as Rezvoi 1928 and Koltun 1959) assigned specimens from Arctic waters to Gellius flagellifer, which could perhaps be members of the present species because Lundbeck's drawing (pl. XIV fig. 1d) of the normal sigmas shows a large size range. However, without the original material this cannot be decided for certain.

Mediterranean records of Gellius vagabundus (cf. Babič 1922), Gellius flagellifer (cf. Vacelet 1969; Pulitzer-Finali 1978, 1983; Pansini 1987) and Haliclona (Gellius) flagellifera (cf. Longo et al. 2005; Sitjà \& Maldonado 2014) could be conspecific with the present species. The depth range of the combined records is 20-809 m. Babič (1922: 228, text-fig. H) provides detailed spicule data that appear to conform to those of the present material, except the upper size of the oxeas $(222-480 \times 2-12 \mu \mathrm{m})$ and the normal sigmas $(15-125 \mu \mathrm{m})$ which are in excess of the North Atlantic material. The other Mediterranean records do not provide details of size categories of normal sigmas, so the conspecificity remains doubtful.

Haliclona (Flagellia) hajdui subgen. et sp. nov. urn:1sid:zoobank.org:act:7F505002-4332-4C79-BCD7-5E3CDEF3A1AB

Figs $15-16$

Desmacella sp. - Schmidt 1870: 53, Pl. V fig. 15.

Haliclona (Gellius) aff. flagellifera - Van Soest 2017: 27, figs 16a-e.

\section{Etymology}

The specific epithet refers to professor Eduardo Hajdu (Museu Nacional de Rio de Janeiro, Brazil) in recognition of his many contributions to our knowledge of the sponge fauna of South America.

\section{Material examined}

Holotype

SURINAME: 'Luymes O.C.P.S.II' Guyana Shelf Expedition, station M97, 7.3083 N, $54.1667^{\circ} \mathrm{W}$, depth 130 m, bottom coarse sand, 16 Apr. 1969 (RMNH Por. 9921).

\section{Paratypes}

SURINAME: same collection data as for holotype (RMNH Por. 9783, 9851).

\section{Description}

Encrusting to irregular lamellar with oscular lobes (Fig. 15A-C). The three samples were obtained from the same station, but some were fragmented into small $\mathrm{cm}$-sized pieces making it difficult to describe the overall shape in more detail. The specimen chosen as the holotype is basically an oscular lobe of $1.5-2 \mathrm{~cm}$ high and wide, with an oscule of $3 \mathrm{~mm}$ in diameter, the paratypes are fragments, partially overgrowing dead parts of associated organisms, including sponges. The surface is irregular, punctate. The color (in alcohol) ranges from shades of pinkish light or darker brown. The consistency is soft and fragile. 
Skeleton (Fig. 15D). The choanosome shows a loose reticulation of ascending tracts which have 2-3 spicules in cross section, and interconnecting single spicules, but overall the skeleton is confused without binding spongin. The surface skeleton is unispicular, but is discontinuous where there are large subdermal spaces. In places microscleres are crowding the spaces between the spicules, with normal sigmas the most common.

OXeas (Fig. 16A-A1). Slightly curved, elongate-fusiform, 226-319-358 × 11-12.7-14 $\mu \mathrm{m}$.

Flagellosigmas (Fig. 16B-D). Predominantly elliptical, with a large difference in length between the long and short endings, in a single widely variable size category. Long endings predominantly upturned with sharply bent curvature, occasionally with short straight curvature, short endings deeply and rather narrowly curved. Length of long endings $66-106-159 \mu \mathrm{m}$, of short endings $42-75-86 \mu \mathrm{m}$, width 40 63-81 $\mu \mathrm{m}$, thickness $1.5-2.4-3.5 \mu \mathrm{m}$.

Normal sigmas (Fig. 16E). Symmetrical, with slightly incurving apices, 42-53.6-72 $\times 2-2.1-2.5 \mu \mathrm{m}$.
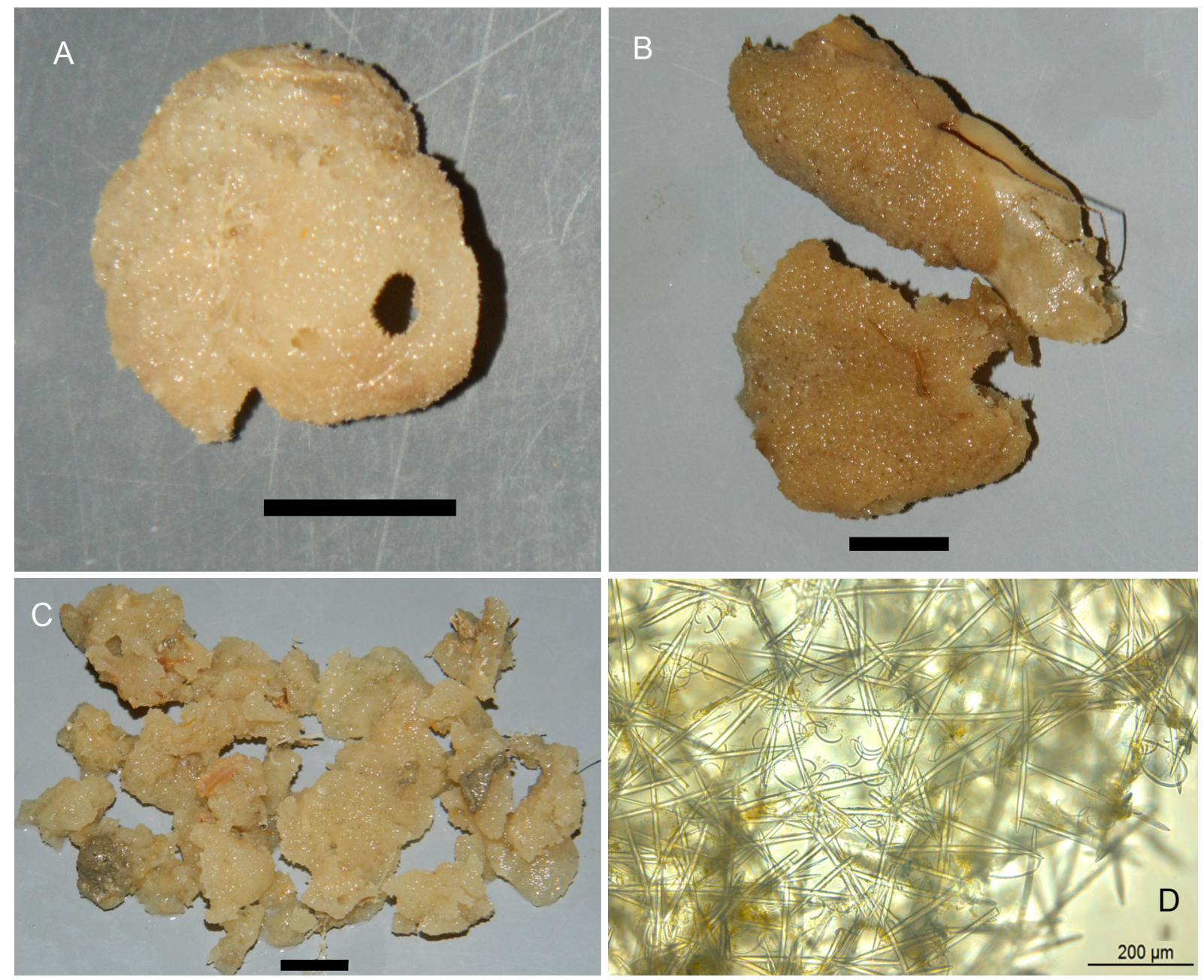

Fig. 15. Haliclona (Flagellia) hajdui subgen. et sp. nov., from the Guyana Shelf, off Suriname. A. Habitus of holotype (RMNH Por. 9921). B. Habitus of paratype (RMNH Por. 9851). C. Habitus of paratype (RMNH Por. 9783). D. Light microscopic image of surface skeleton of holotype (RMNH Por. 9921), showing scattered flagellosigmas and sigmas. Scale bars $=1 \mathrm{~mm}$. 


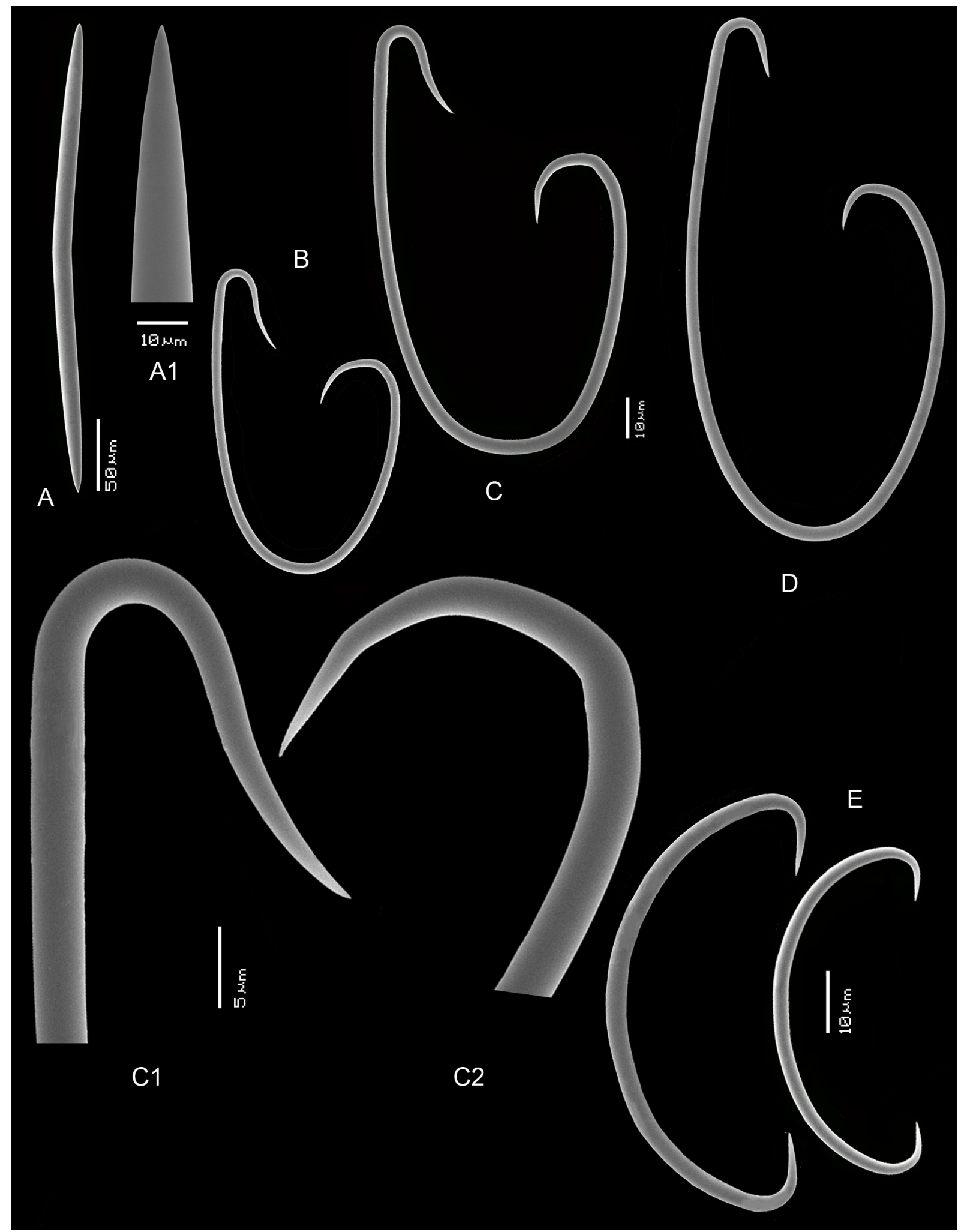

Fig. 16. Haliclona (Flagellia) hajdui subgen. et sp. nov., from the Guyana Shelf, off Suriname, holotype, SEM images of spicules (RMNH Por. 9921). A. Oxea. A . Detail of one of the apices. B-D. Flagellosigmas. $\mathbf{C}_{1}$. Detail of long ending of flagellosigma. $\mathbf{C}_{2}$. Detail of short ending of flagellosigma. E. Sigmas. 


\section{Distribution and ecology}

Collected on the upper continental slope off Suriname at a depth of $130 \mathrm{~m}$ (Marine Ecoregion Guianan). If Schmidt's report of Desmacella spec. is conspecific then it is likely to occur elsewhere in deeper water in the Greater Caribbean.

\section{Remarks}

The new species has characteristically elliptic flagellosigmas which also have upturned long endings. They resemble the drawing of the flagellosigma of a specimen from Kerguelen (cf. Boury-Esnault \& Van Beveren 1992), assigned probably erroneously to Haliclona (Gellius) flagellifera. Other aspects (oxea size and sigma sizes) are quite different, so close relationship is not likely.

Van Soest (2017) mentioned the presence of this species in a another northern South American locality, off the coast of Caribbean Colombia. However, after careful comparison of this material (ZMA Por. 21962) it is not very likely that it belongs to this species, as the flagellosigmas are shaped differently. Instead, this specimen is considered an unnamed Haliclona (Flagellia) to be described fully if and when sufficient material is obtained.

Furthermore, Van Soest (2017) repeated earlier records of Haliclona (Flagellia) from the Turneffe Islands, Belize, made by Van Soest (1980) and De Weerdt (2000) based on undescribed material in the Natural History Museum, London. Brief notes on this material do not allow unequivocal assignment of it to any of the species treated here.

\section{Haliclona (Flagellia) sp.}

Fig. 17

? Sigmadocia flagelifer [sic] Kaminskaya, 1971: 116.

? Haliclona sp. 2 Alcolado, 2002: 67.

\section{Material examined}

COLOMBIA: Santa Marta, Punta de Betín, $11.2503^{\circ}$ N, $74.2207^{\circ} \mathrm{W}, 20 \mathrm{~m}$ deep, SCUBA, coll. M. Kielman, field number SM 132, 1991 (ZMA Por. 21962).

\section{Description}

Small fragment, approximately $2 \times 2 \times 1 \mathrm{~mm}$ in size. Color in alcohol dark brown. Consistency soft.

SKELETon. Confused, a largely unispicular reticulation of oxeas. Few microscleres.

OXEAS (Fig. 17A-A1). Straight, relatively thin, sharply pointed, 232-289-315 × 8-10.2-13 $\mu \mathrm{m}$.

Flagellosigmas (Fig. 17B-C). Only six were found; these are circular to ovoid in outline, with long endings with short straight apices, with short endings widely curved. Length of long endings (Fig. 17B1) 70-82-95 $\mu \mathrm{m}$, of short endings (Fig. 17B2) 50-58-63 $\mu \mathrm{m}$, width 55-61-75 $\mu \mathrm{m}$, thickness $2-2.4-3 \mu \mathrm{m}$.

Normal sigmas (Fig. 17D). Robust, symmetrical, strongly incurved apices, 39-46.1-53 × 1.5-2.6$3.5 \mu \mathrm{m}$.

\section{Distribution and ecology}

Colombian Caribbean, reef environment at a depth of $20 \mathrm{~m}$ (Marine Ecoregion Southern Caribbean). Possibly Cuba (Marine Ecoregion Greater Antilles), 5-9 m depth (see Remarks below). 


\section{Remarks}

Although the shapes of the flagellosigmas and the sigmas clearly differ from those of the above described $H$. (F.) hajdui subgen. et sp. nov., this material is not named here because it is too small to allow proper study. Only a few flagellosigmas were found, leaving open the possibility that larger spicules with upturned apices and a more elliptical outline might have been missed. Future study is necessary to delimit the characters of this species against those of $H$. (F.) hajdui subgen. et sp. nov.

Alcolado (2002) cited Haliclona sp. 2 based on a description of Kaminskaya (1971) of a specimen named Sigmadocia flagellifera from Northwestern Cuba, soft bottom at 5-9 m depth. Oxeas were 115$220 \times 3-5 \mu \mathrm{m}$, well below the above measurements, sigmas were cited as 16-64 $\mu \mathrm{m}$, not differentiated

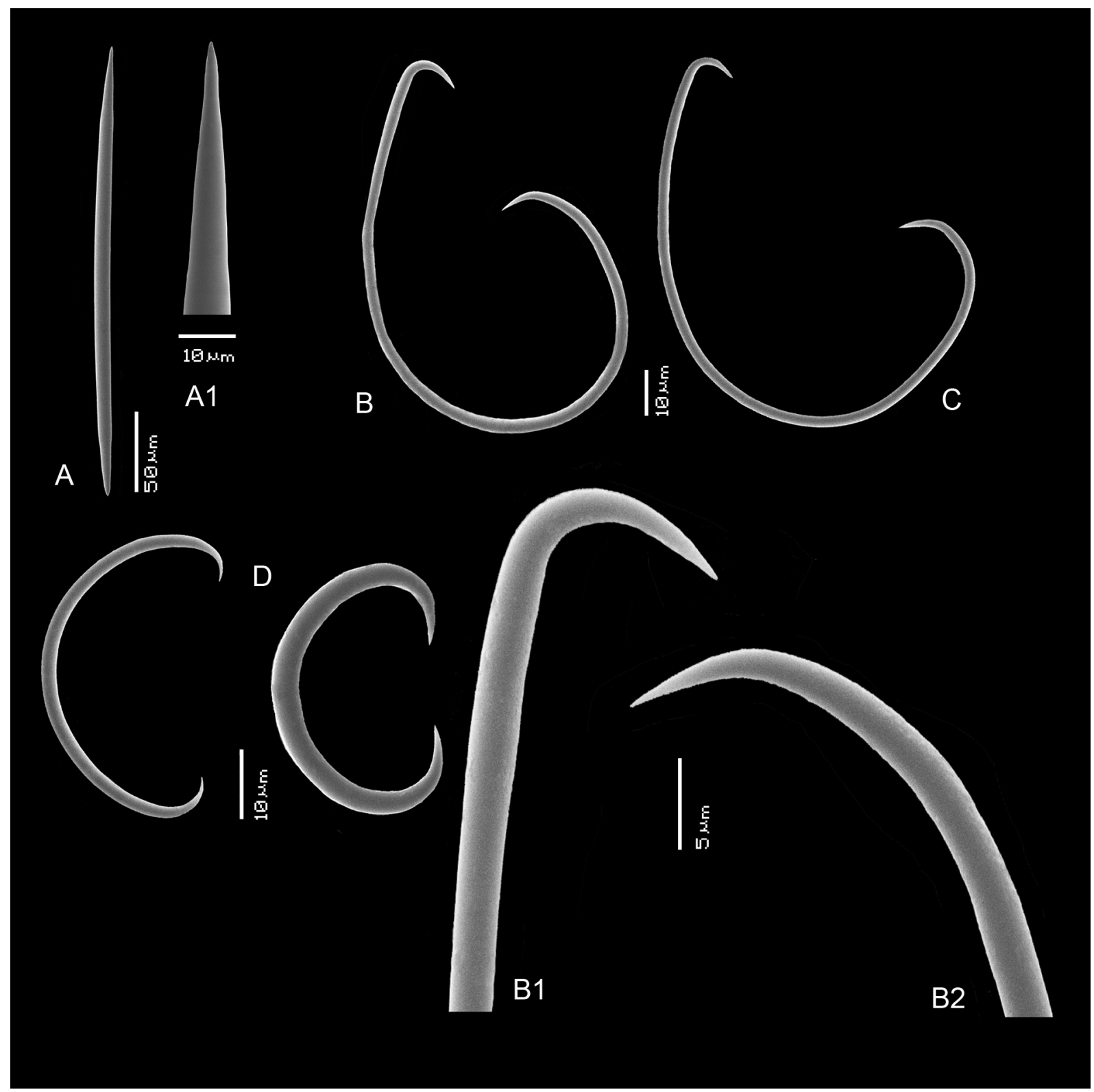

Fig. 17. Haliclona (Flagellia) sp., from Santa Marta, Colombia, SEM images of the spicules (ZMA

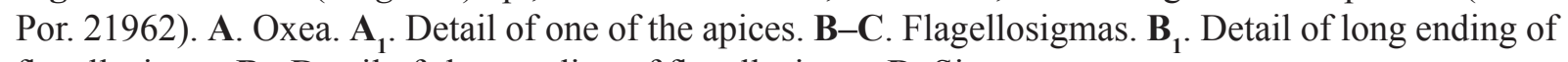
flagellosigma. $\mathbf{B}_{2}$. Detail of short ending of flagellosigma. D. Sigmas. 
into flagellosigmas and normal sigmas. These data are insufficient to determine if this record were conspecific with the Colombian specimen.

Haliclona (Flagellia) edaphus (De Laubenfels, 1930) subgen. et comb. nov. Fig. 18

Gellius edaphus De Laubenfels, 1930: 28.

? Sigmadocia edaphus - Dickinson 1945: 12, pl. 14 figs 27-28, pl. 15 fig. 29. — Green \& Bakus 1994: 46, fig. 27.

Xestospongia edapha Lee et al. 2007: 110 (redescription of holotype).

Gellius edaphus - De Laubenfels 1932: 111, fig. 66.

? non Gellius edaphus - Sim \& Kim 1988: 27, pl. 2 figs 3-4.

\section{Material examined}

UNITED STATES OF AMERICA: small 'wet' fragment of holotype (USNM 21444), California, Carmel, Pescadero Point, 36.5037 N, $121.9357^{\circ}$ W, intertidal cave, coll. M.W. De Laubenfels, Jul. 1926.

Description (from De Laubenfels 1932: 111-112)

A thick plate-like mass $(40 \times 30 \times 20 \mathrm{~cm})$ encrusting stones in an intertidal cave. Color whitish in life and in alcohol. Surface smooth. Oscules of about $1 \mathrm{~mm}$ diameter are distributed evenly over the upper surface. Consistency firm to hard.

SKeleton. Dense, confused reticulation of thick oxeas. At the surface single spicules are arranged tangentially.

OXEAS (Fig. 18A-A1). Curved, cigar-shaped, sharply pointed, 272-314-342 × 12-15.8-17 $\mu \mathrm{m}$ (De Laubenfels gives $260-270 \times 15-16 \mu \mathrm{m})$.

Flagellosigmas (Fig. 18B-C). Elliptical in outline, with relatively large difference in length of long and short endings. Long endings with sharp curvature ending straight with a faint upturn in many spicules, short endings widely curved with only modest incurved apices. Length of long endings 76-89-105 $\mu \mathrm{m}$, short endings 64-67-72 $\mu \mathrm{m}$, width 53-66-81 $\mu \mathrm{m}$, thickness 1.5-2.95-3.5 $\mu \mathrm{m}$. De Laubenfels did not differentiate flagellosigmas from normal sigmas, his drawing shows only a flagellosigma, sizes quoted by him were $30-100 \mu \mathrm{m}$.

Normal SIGMAS (Fig. 18D). Not very common. Shape robust, symmetrical, apices sharply curved but not incurved, with many thin growth stages (not included in meaurements), 37-63.9-81 $\times 2.5-3.3-4 \mu \mathrm{m}$. De Laubenfels did not mention the presence of 'normal' sigmas.

\section{Distribution and ecology}

California, near Carmel (Marine Ecoregion Northern California). Apparently confined to intertidal and shallow subtidal rocks. De Laubenfels mentions a second locality for this species, Point Fermin, near San Pedro (33.7054 N, 118.2938 W) (Marine Ecoregion Southern Californian Bight).

\section{Remarks}

Lee et al. 2007 redescribed the holotype (as Xestospongia edapha) and provided SEM evidence of the presence of both flagellosigmas and normal sigmas. They gave oxea sizes as 260-275-300 $\times 12-13-15$, flagellosigmas 75-(87-96)-118, and normal sigmas 46-(52-81)-118 $\mu \mathrm{m}$. Except for the highest value 
of sigma length (which may be a misprint as it is the same as the upper size of the flagellosigmas), their data conform to the present description and are slightly different from De Laubenfels' original description. Lee et al. (2007) provided illustrations of the holotype and of its skeleton. They treated the name edaphus as an adjective (by adjusting the combination with the genus Xestospongia to edapha), but it is a noun from the Greek, meaning bottom or pavement. For that reason, the name edaphus in its original spelling is retained here.

Dickinson (1945) reported this species from the (Mexican) Gulf of California (Carmen Island, approximately $25.94^{\circ} \mathrm{N}, 111.09^{\circ} \mathrm{W}$ ) at a depth of $120 \mathrm{~m}$. The oxeas of his specimen measured up

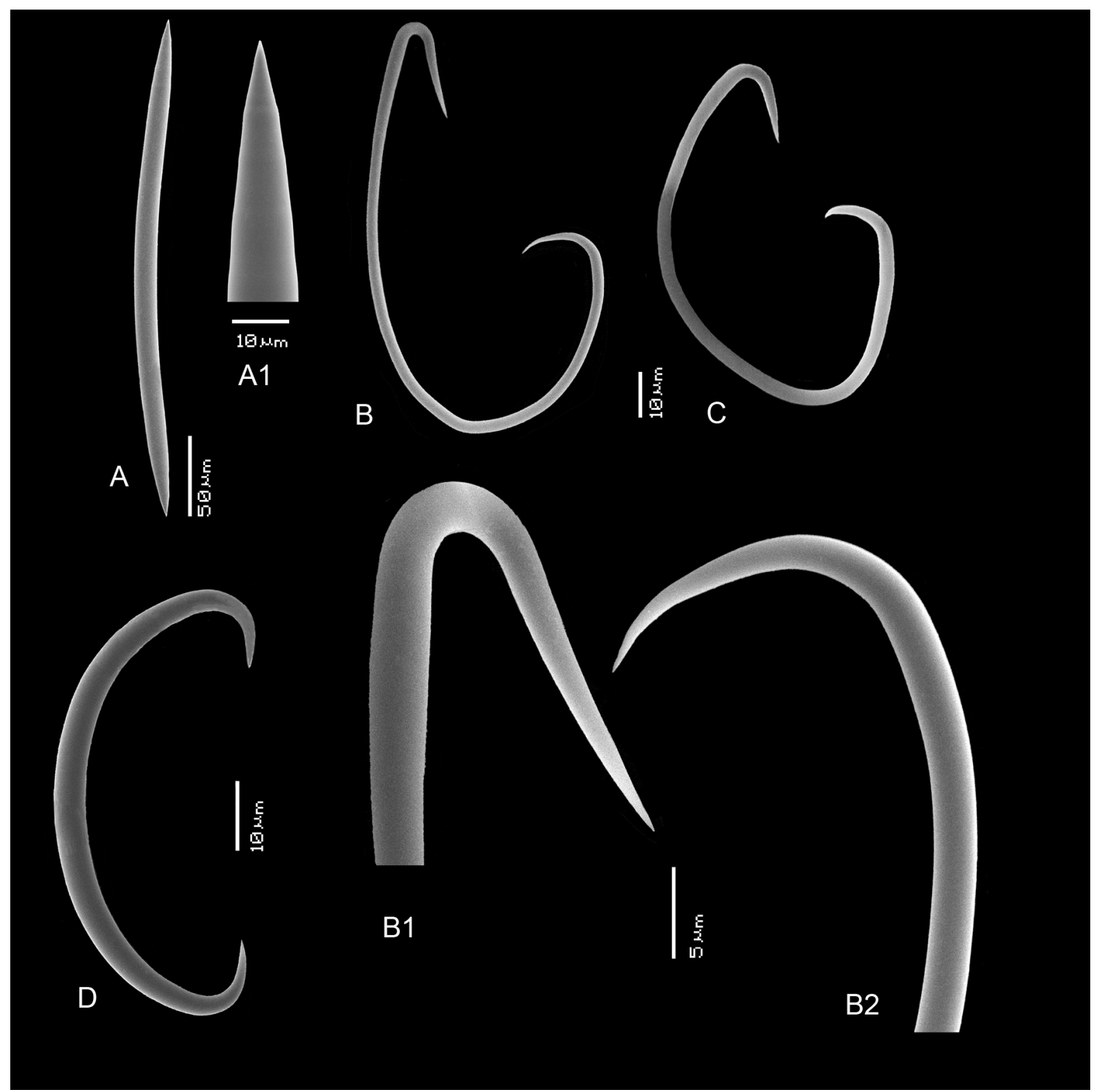

Fig. 18. Haliclona (Flagellia) edaphus (De Laubenfels, 1930) from California, SEM images of the spicules made from a fragment of the holotype (USNM 21444). A. Oxea. A. Detail of one of the apices. B-C. Flagellosigmas. $\mathbf{B}_{1}$. Detail of long ending of flagellosigma. $\mathbf{B}_{2}$. Detail of short ending of flagellosigma. D. Sigma. 
to $400 \times 18 \mu \mathrm{m}$ and like De Laubenfels he did not differentiate flagellosigmas from normal sigmas, averaging them together as $40 \mu \mathrm{m}$. His pl. 15 fig. 29 shows a 'distorted' flagellosigma, which from the magnification provided has a long ending of about $60 \mu \mathrm{m}$ long, with prominent long upturned curvature. Depth occurrence, larger oxeas and long upturned endings on the flagellosigmas together indicate a likely different species.

Green \& Bakus (1994) reported two specimens, one from a depth of 54-63 m and one from $200 \mathrm{~m}$, collected from the Santa Maria Basin off the coast of Southern California. The descriptions are somewhat confused, and apparently the spicule measurements between the two specimens varied widely. Possibly, the specimen from 54-63 m could conform to $H$. (F.) edaphus, but the one from $200 \mathrm{~m}$ deep appears to be different as the authors gave 'sigma' measurements of 13-250 $\mu \mathrm{m}$, which are not compatible with the sizes from $H$. $(F$.) edaphus. Assignment of these deep-water California records awaits proper redescription of the specimens.

Sim \& Kim's (1988) record of Gellius edaphus from 145 m depth off South Korea $\left(33^{\circ} \mathrm{N}, 127.5^{\circ} \mathrm{E}\right)$ is likewise uncertain, as the long ending of the pictured flagellosigma is smaller than $50 \mu \mathrm{m}$. Combined with the large geographic distance from the type locality in California, this is sufficient indication of unlikely conspecificity.

Additional species reassigned to Haliclona (Flagellia) subgen. nov.

Haliclona (Flagellia) anataria (Lévi \& Lévi, 1983) subgen. et comb. nov.

Gellius anatarius Lévi \& Lévi, 1983: 976, fig. 37.

Description (from Lévi \& Lévi 1983)

Small grey specimen of $2 \times 4 \mathrm{~mm}$ encrusting the internal valve of a bivalve mollusk. The surface and interior is clathrate, with cavities of $0.5-2 \mathrm{~mm}$ diameter. The skeletal architecture is reticulated and irregularly unispicular. Oxeas are 650-800 $\times 25-30 \mu \mathrm{m}$, flagellosigmas ovoid with upturned long endings and wide-angled short endings, longest axis $125-130 \mu \mathrm{m}$, width $70-85 \mu \mathrm{m}$, normal sigmas (common) $100-120 \times 2-3 \mu \mathrm{m}$.

\section{Distribution and ecology}

New Caledonia, 22.5333ㅇ S, $166.4167^{\circ}$ E, depth 430-500 m (Marine Ecoregion New Caledonia).

\section{Remarks}

The name anatarius ('duck-like', referring to the upturned long ending) is changed to anataria to match the female gender of Haliclona. Due to the large oxeas and sigmas this species can clearly be associated with the known species of Haliclona (Flagellia) subgen. nov. The flagellosigmas are similar in shape to those of species from nearby Indonesia $(H$. (F.) indonesiae subgen. et sp. nov., $H$. (F.) hamata, $H$. (F.) hentscheli subgen. et nom. nov.), of the Seychelles species $H$. (F.) amirantensis subgen. et sp. nov., and to a lesser extent of the Guyanan $H$. (F.) hajdui subgen. et sp. nov.

Lévi (1993) provided an additional New Caledonia deep-water $(500 \mathrm{~m})$ record of material belonging to Haliclona (Flagellia) subgen. nov. (reported as a Gellius flagellifer), which is definitely not assignable to $H$. (F.) anataria, as it has oxeas of 300-350 $\times 10 \mu \mathrm{m}$, flagellosigmas with straight long endings, $70-105 \mu \mathrm{m}$, and two size categories of sigmas, $25-35$ and $40-55 \mu \mathrm{m}$. Further study is necessary to determine whether it belongs to $H$. (F.) flagellifera or perhaps to one of the above described species, e.g., $H$. $(F$.) hentscheli subgen. et nom. nov. 


\section{Haliclona (Flagellia) spp.}

Based on literature data only, it is not possible to estimate which of the many records of Gellius/ Desmacella/Sigmadocia/Adocia/Hemigellius/Haliclona flagellifer(a), vagabundus(a), and edaphus(a) (see above in the historic overview and in the Remarks sections of the species) are assignable to already named species. A non-exhaustive list of references to potential additional separate species is presented here, following the same geographic order as presented in this study.

(1) Andaman Sea, deep water (cf. Burton 1928)

(2) Southern Red Sea (cf. Burton 1959b)

(3) Kerguelen Islands (cf. Boury-Esnault \& Van Beveren 1992)

(4) New Zealand (cf. Dendy 1924; Bergquist \& Warne 1980)

(5) Antarctica (cf. Burton 1938; Göcke \& Janussen 2013)

(6) South Africa, shallow water (cf. Samaai \& Gibbons 2005)

(7) Namibia, deep water (cf. Uriz 1987, 1988)

(8) California, deep water (cf. Green \& Bakus 1994)

(9) Baja California (cf. Dickinson 1945)

(10) Japan (cf. Hoshino 1981)

(11) Korea (cf. Sim \& Kim 1988)

\section{Discussion}

From the descriptions presented above, specific differences between member species of Haliclona (Flagellia) subgen. nov. are in aspects of habitus, flagellosigma size categories and shapes, and sigma size categories. Together these differences allow the morphological differentiation of at least 11 species, summarized here in Table 1. Shapes are most often encrusting to small-massive, but three species $H$. (F.) indonesiae subgen. et sp. nov., $H$. (F.) hamata and $H .(F$.$) edaphus) are more substantial in$ having large plate-like, massive or arborescent shapes. Oxeas in most species have their length usually between 180 and $420 \mu \mathrm{m}$, but thickness is quite variable. $H$. $(F$.) anataria is exceptional in having oxeas of 650-800 $\mu \mathrm{m}$ long. At least five species $(H$. (F.) indonesiae subgen. et sp. nov., H. (F.) hamata, $H$. (F.) hentscheli subgen. et nom. nov., $H$. (F.) amirantensis subgen. et sp. nov., H. (F.) hajdui subgen. et sp. nov. and $H$. $(F$.) anataria) have characteristically upturned long endings of the flagellosigmas, and all of these are tropical species. However, at least one species, a so-far unnamed specimen from a cold-water locality (reported as Gellius flagellifer by Boury-Esnault \& Van Beveren (1982) from Kerguelen), also has flagellosigmas ornamented with upturned endings. Furthermore, such long endings have not been found in tropical $H$. $(F$.) spec. from Colombia described above. Therefore, it is too early to conclude that this feature is a character found only in tropical species. The difference in shape of the flagellosigmas between species is often subtle, but there are species with predominantly circular flagellosgimas $(H$. $(F$.$) indonesiae subgen. et sp. nov., H$. $(F$.$) hamata, H$. $(F$.) hentscheli subgen. et nom. nov., $H$. $(F$.) amirantensis subgen. et sp. nov., and $H$. $(F$.) sp. from Colombia) and species with more elliptical flagellosigmas $(H$. (F.) edaphus, $H$. $(F$.) flagellifera, $H$. $(F$.) porosa, and $H$. (F.) hajdui subgen. et sp. nov.). The remaining species $(H$. $(F$. hiberniae subgen. et sp. nov. and $H$. (F.) anataria $)$ have ovoid flagellosigmas. Three species $(H$. (F.) hentscheli subgen. et nom. nov, $H$. $(F$.) flagellifera and $H$. (F.) hiberniae subgen. et sp. nov.) exhibit size differentiation in the flagellosigmas, with very large and very small flagellosigmas, often also different in shape, occurring in the same individual. This is not individual variation or growth stages, because the many (25+) collected specimens of $H$. ( $F$.) hiberniae subgen. et sp. nov. all showed the same division into larger and smaller flagellosigmas, although the extent of the size difference varied. Three species $(H$. $(F$.) hentscheli subgen. et nom. nov., $H$. $(F$.) amirantensis subgen. et sp. nov. and $H$. (F.) hiberniae subgen. et sp. nov.) have two distinct size categories of normal sigmas, which further distinguishes them. Shape and size of these sigmas may also be subtly distinctive 


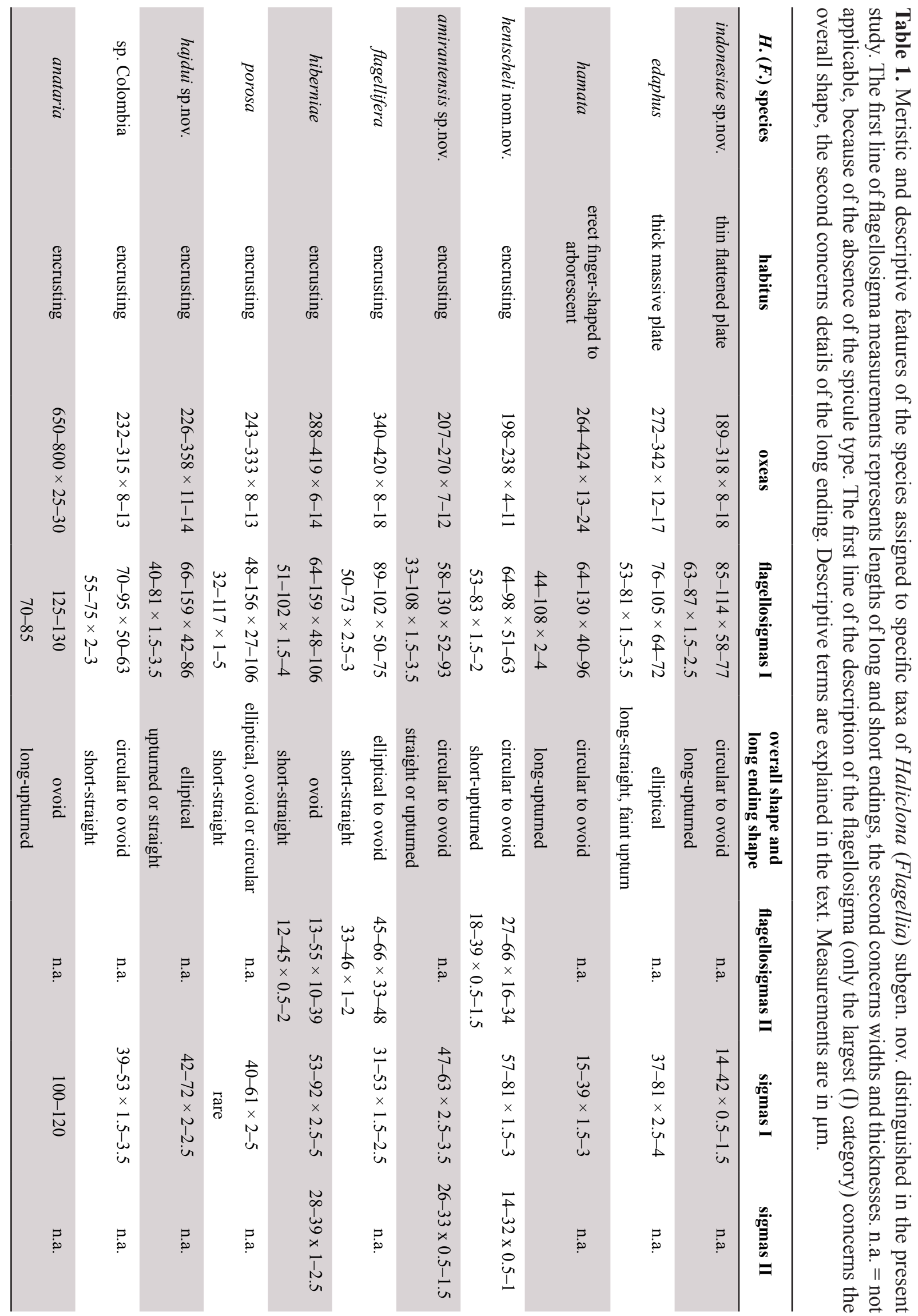


among species, as seen in $H$. $(F$.) indonesiae subgen. et sp. nov. and $H$. (F.) hamata, where they differ in the thickness of these spicules.

Characters with little or no differentiation among the species appear to be color and skeletal structure. All species have colors in shades of light brown or dirty white and skeletons are usually confusedpaucispicular. Some species have visible quantities of spongin, partially enveloping spicule tracts, notably $H$. (F.) indonesiae subgen. et sp. nov., $H$. (F.) hamata and to a lesser extent $H$. (F.) amirantensis subgen. et sp. nov.

While detailed comparisons of the specimens available in this study reveal small differences between them, it is striking to note that specimens from widely separate localities exhibit a basically uniform skeletal structure and spicule complement. Assuming this basic morphology as evidence for monophyly, it is likely to mean that the subgenus Flagellia subgen. nov. has had a long history, possibly going back to Mesozoic times when interocean corridors were in place and continental platforms and slopes were generally interconnected. Such an age would appear to be in conflict with the status of subgenus and would justify raising it to genus level as ubiquitous distributions are more likely at the genus level. However, currently the status of the family Chalinidae requires a systematic review, including morphological taxonomy in parallel with molecular techniques, the outcome of which may affect the status of many of the genus names presently subsumed under the synonymy of Haliclona s.l. It is prudent to refrain from adding to the genus level content of the family and its order until a molecular tree of genera (based on sequences of their type species) is available.

\section{Acknowledgements}

Nicole de Voogd (Naturalis Biodiversity Center) collected and photographed the holotype of Haliclona (Flagellia) indonesiae subgen. et sp. nov. Elly Beglinger (Naturalis Biodiversity Center) assisted with the registration and management of the specimens. Thanks are due to the curators of the Natural History Museum, London, and the Senckenberg Museum, Frankfurt, for allowing the sampling of type specimens in their care (Gellius flagellifer and Gelliodes hamata). Klaus Rützler (Smithsonian Institution, Natural History Museum) kindly allowed me to take a fragment of the type of Gellius edaphus. The constructive input from two anonymous reviewers is gratefully acknowledged.

\section{References}

Alcolado P.M. 2002. Catálogo de las esponjas de Cuba. Avicennia 15: 53-72.

Babič K. 1922. Monactinellida und Tetractinellida des Adriatischen Meeres. Zoologische Jahrbücher Abteilung für Systematik, Geographie und Biologie der Tiere 46 (2): 217-302.

Bakus G.D. \& Green K.D. 1994. The Porifera. In: Blake J.A. \& Lissner A.L. (eds) Taxonomic Atlas of the Benthic Fauna of the Santa Maria Basin and Western Santa Barbara Channel, Volume 2. Santa Barbara Museum of Natural History, Santa Barbara.

Bergquist P.R. \& Warne K.P. 1980. The marine fauna of New Zealand: Porifera, Demospongiae, part 3 (Haplosclerida and Nepheliospongida). New Zealand Oceanographic Institute Memoir 87: 1-77.

Boury-Esnault N. \& Van Beveren M. 1982. Les Démosponges du plateau continental de KerguelenHeard. Comité national français des recherches antarctiques 52: 1-175.

Brøndsted H.V. 1933. The Godthaab Expedition 1928. Porifera. Meddelelser om Grønland 79 (5): 1-25.

Burton M. 1928. Report on some deep-sea sponges from the Indian Museum collected by R.I.M.S. 'Investigator'. Part II. Tetraxonida (concluded) and Euceratosa. Records of the Indian Museum 30 (1): $109-138$. 
Burton M. 1930. Norwegian sponges from the Norman collection. Proceedings of the Zoological Society of London 1930 (2): 487-546. https://doi.org/10.1111/j.1096-3642.1930.tb00989.x

Burton M. 1938. Non-Calcareous sponges. Scientific Reports of the Australasian Antarctic Expedition 1911-1914 (C. Zoology and Botany) 9 (3): 5-22.

Burton M. 1940. Las esponjas marinas del Museo Argentino de Ciencias Naturales. (Invertebrados Marinas, Publication 6)Annales del Museo Argentino de Ciencias Naturales 40 (Invertebrados Marinas, Publication 6): 95-121.

Burton M. 1959a. Spongia. In: Fridriksson A. \& Tuxen S.L. (eds) The Zoology of Iceland 2 (3-4): 1-71. Ejnar Munksgaard, Copenhagen and Reykjavik.

Burton M. 1959b. Sponges. The John Murray Expedition 1933-34 Scientific Reports 10 (5): 151-281. Trustees of the British Museum (Natural History). Available from http://biodiversitylibrary.org/page/49512735 [accessed 5 Sep. 2017].

Carter H.J. 1887. Report on the marine sponges, chiefly from King Island, in the Mergui Archipelago, collected for the Trustees of the Indian Museum, Calcutta, by Dr. John Anderson, F.R.S., Superintendent of the Museum. Journal of the Linnean Society, Zoology 21 (127-128): 61-84. https://doi.org/10.1111/j.1096-3642.1887.tb00381.x

Czerniavsky V. 1880 [1879]. Spongiae littorales Pontis Euxini et maris Caspii. Continuatio. Bulletin de la Société impériale des naturalistes de Moscou 54 (3): 88-128, 228-320. [In Russian.]

De Laubenfels M.W. 1930. The sponges of California. Abstracts of dissertations for the degree of doctor of philosophy. Stanford University Bulletin 5 (98): 24-29.

De Laubenfels M.W. 1932. The marine and fresh-water sponges of California. Proceedings of the United States National Museum 81 (2927): 1-140.

De Laubenfels M.W. 1949. The sponges of Woods Hole and adjacent waters. Bulletin of the Museum of Comparative Zoology at Harvard College 103 (1): 1-55. Available from http://www.biodiversitylibrary.org/item/21254\#page/5/mode/1up [accessed 25 Jul. 2017].

Dendy A. 1922. Report on the Sigmatotetraxonida collected by H.M.S. 'Sealark' in the Indian Ocean. Reports of the Percy Sladen Trust Expedition to the Indian Ocean in 1905, Volume 7. Transactions of the Linnean Society of London (2) 18 (1): 1-164. https://doi.org/10.1111/j.1096-3642.1922.tb00547.x

Dendy A. 1924. Porifera. Part I. Non-Antarctic sponges. British Antarctic ("Terra Nova") Expedition, 1910. Natural History Reports (Zoology) 6 (3): 269-392. Available from http://www.biodiversitylibrary.org/item/195204\#page/7/mode/1up [accessed 25 Jul. 2017].

De Weerdt W.H. 1986. A systematic revision of the north-eastern Atlantic shallow-water Haplosclerida (Porifera, Demospongiae): 2. Chalinidae. Beaufortia 36 (6): 81-165. Available from http://www.repository.naturalis.nl/record/505186 [accessed 25 Jul. 2017].

De Weerdt W.H. 2000. A monograph of the shallow-water Chalinidae (Porifera, Haplosclerida) of the Caribbean. Beaufortia 50 (1): 1-67. Available from http://www.repository.naturalis.nl/record/505081 [accessed 25 Jul. 2017].

De Weerdt W.H. 2002. Family Chalinidae Gray, 1867. In: Hooper J.N.A. \& Van Soest R.W.M. (eds) Systema Porifera. A Guide to the Classification of Sponges 1: 852-873. Kluwer Academic/Plenum Publishers, New York, Boston, Dordrecht, London, Moscow.

Dickinson M.G. 1945. Sponges of the Gulf of California. In: Allan Hancock Pacific Expediitions. First Series 11 (1): 1-55. Allan Hancock Foundation Publications of the University of Southern California, California. Available from http://biodiversitylibrary.org/page/5215603 [accessed 5 Sep. 2017]. 
Ferrer Hernández F. 1918. Esponjas del litoral de Asturias. Trabajos del Museo Nacional de Ciencias Naturales Serie Zoologia 36: 1-39.

Ferrer Hernández F. 1923. Más datas para el conocimiento de las esponjas de las costas espanolas. Boletim de Pescas 7: 247-272.

Fristedt K. 1887. Sponges from the Atlantic and Arctic Oceans and the Behring Sea. Vega-Expeditionens Vetenskap. Iakttagelser (Nordenskiöld) 4: 401-471.

Ginn B.K. 1997. Ecology, Systematics and Feeding Rate of Sponges on Subtidal Hard Substrates in Little Passage, Deer Island, New Brunswick. PhD Thesis, University of New Brunswick, Canada.

Ginn B.K., Logan A., Thomas M.L.H. \& Van Soest R.W.M. 1998. Hymedesmia canadensis (Porifera: Poecilosclerida), a new species among new geographical records from the Bay of Fundy, New Brunswick, Canada. Journal of the Marine Biological Association of the United Kingdom 78: 1093-1100. https://doi.org/10.1017/S0025315400044349

Göcke C. \& Janussen D. 2013. Demospongiae of ANT XXIV/2 (SYSTCO I) Expedition, Antarctic Eastern Weddell Sea. Zootaxa. 3692 (1): 28-101. https://doi.org/10.11646/zootaxa.3692.1.5

Gosner K.L. 1971. Guide to Identification of Marine and Estuarine Invertebrates, Cape Hatteras to the Bay of Fundy. Wiley-Interscience, John Wiley \& Sons, Inc., New York.

Gulliksen B., Palerud R., Brattegard T. \& Sneli J. (eds) 1999. Distribution of Marine Benthic MacroOrganisms at Svalbard (Including Bear Island) and Jan Mayen. Research Report for DN 1999-4. Directorate for Nature Management. Available from http://www.miljodirektoratet.no/old/dirnat/ attachment/1957/Utredning\%201999-4\%20Distribution\%20of\%20marine.pdf [accessed 25 Jul. 2017].

Hentschel E. 1912. Kiesel- und Hornschwämme der Aru- und Kei-Inseln. Abhandlungen herausgegeben von der Senckenbergischen naturforschenden Gesellschaft 34 (3): 293-448.

Hentschel E. 1916. Die Spongien des Eisfjords. In: Zoologische Ergebnisse der Schwedischen Expedition nach Spitzbergen, 1908. Teil II. Kungliga Svenska vetenskapsakademiens Handlingar 54 (3): 1-18.

Hentschel E. 1929. Die Kiesel- und Hornschwämme des Nördlichen Eismeers. In: Römer F., Schaudinn F., Brauer A. \& Arndt W. (eds) Fauna Arctica. Eine Zusammenstellung der arktischen Tierformen mit besonderer Berücksichtigung des Spitzbergen-Gebietes auf Grund der Ergebnisse der Deutschen Expedition in das Nördliche Eismeer im Jahre 18985 (4): 857-1042. G. Fischer, Jena.

Hoshino T. 1981. Shallow-water Demosponges of Western Japan, 1. Journal of Science of the Hiroshima University (Series B) 29 (1): 47-205.

Hoshino T. 1987. A preliminary catalogue of the marine species of the class Demospongia (PORIFERA) from Japanese waters. Mukaishima Marine Biological Station, Hiroshima University, Contribution 279: 1-48.

Kaminskaya L.D. 1971. Sponges of the upper sublittoral of the north-western part of the Cuban platform. Issledovania Centralno Amarikanskij Morei 3: 112-121. [In Russian with English summary.]

Kelly M., Edwards A.R., Wilkinson M.R., Alvarez B., Cook S. de C., Bergquist P.R., Buckeridge J.S., Campbell H.J., Reiswig H.M., Valentine C. \& Vacelet J. 2009. Phylum Porifera: Sponges. In: Gordon D.P. (ed.) New Zealand Inventory of Biodiversity: 1. Kingdom Animalia: Radiata, Lophotrochozoa, Deuterostomia: 23-46. Canterbury University Press, Christchurch.

Koltun V.M. 1959. [Siliceous Horny Sponges of the Northern and Far Eastern Seas of the U.S.S.R.] Opredeliteli po faune SSR, izdavaemye Zoologicheskim muzeem Akademii nauk 67: 1-236. [In Russian, English translation 1971 by the Fisheries Research Board of Canada Translation Series 1842: 1-442.] 
Koltun V.M. 1962. Four rayed and siliceous horny sponges from the Pacific shallow waters of Paramushir and Shumshu Islands. Issledovaniya dal'nevostochnykh morei SSSR 8: 181-199. [In Russian.]

Koltun V.M. 1964. Sponges of the Antarctic. 1. Tetraxonida and Cornacuspongida. In: Pavlovskii E.P., Andriyashev A.P. \& Ushakov P.V. (eds) Biological Reports of the Soviet Antarctic Expedition (19551958): 6-133, 443-448. Akademya Nauk SSSR. [English translation 1966 by the Israel Program for Scientific Translation: 1-131.]

Lambe L.M. 1896. Sponges from the Atlantic coast of Canada. Transactions of the Royal Society of Canada, Section 2 (2) 2: 181-211.

Lee W.L., Elvin D.W. \& Reiswig H.M. 2007. The Sponges of California. A Guide and Key to the Marine Sponges of California. Monterey Bay Sanctuary Foundation, Monterey.

Lehnert H. \& Stone R.P. 2016. A comprehensive inventory of the Gulf of Alaska sponge fauna with the description of two new species and geographic range extensions. Zootaxa 4144 (3): 365-382. https://doi.org/10.11646/zootaxa.4144.3.5

Lemke P. (ed.) 2003. The Expedition ARKTIS XVIII/1a,b of the research vessel 'Polarstern' in 2002. Berichte Polarforschung Meeresforschung 446: 1-118.

Lévi C. 1969. Spongiaires du Vema Seamount (Atlantique Sud). Bulletin du Muséum national d'Histoire naturelle 41 (4): 952-973.

Lévi C. 1993. Porifera Demospongiae: Spongiaires bathyaux de Nouvelle-Calédonie, récoltés par le 'Jean Charcot'. Campagne BIOCAL, 1985. In: Crosnier A. (ed.) Résultats des campagnes MUSORSTOM, Volume 11: 9-87. Mémoires du Muséum national d'Histoire naturelle (A, Zoologie) 158, Muséum national d'Histoire naturelle, Paris.

Lévi C. \& Lévi P. 1983. Démosponges bathyales récoltées par le N/O 'Vauban' au sud de la NouvelleCalédonie. Bulletin du Muséum national d'Histoire naturelle (4, A) 5 (4): 931-997.

Longo C., Mastrototaro F. \& Corriero G. 2005. Sponge fauna associated with a Mediterranean deepsea coral bank. Journal of the Marine Biological Association of the United Kingdom 85: 1341-1352. https://doi.org/10.1017/S0025315405012518

Lundbeck W. 1902. Porifera. (Part I.) Homorrhaphidae and Heterorrhaphidae. In: The Danish Ingolf-Expedition 6 (1): 1-108. Bianco Luno, Copenhagen. Available from http://biodiversitylibrary.org/page/2206232 [accessed 6 Sep. 2017].

Lundbeck W. 1909. The Porifera of East Greenland. Meddelelser om Grønland 29: 423-464.

Pansini M. 1987. Report on a collection of Demospongiae from soft bottoms of the Eastern Adriatic Sea. In: Jones W.C. (ed.) European Contributions to the Taxonomy of Sponges: 41-53. Sherkin Island Marine Station, Sherkin Island, Cork.

Pansini M. \& Sara M. 1999. Taxonomical and biogeographical notes on the sponges of the Straits of Magellan. Scientia Marina 63 (Supl.1): 203-208. https://doi.org/10.3989/scimar.1999.63s1203

Pattanayak J.G. 1999. Annotated checklist of marine sponges of the Indian region. Memoirs of the Queensland Museum 44: 439-455.

Pattanayak J.G. 2006. Marine sponges of Andaman \& Nicobar Islands, India. Records of the Zoological Survey of India. Occasional Paper 255: 1-152.

Pulitzer-Finali G. 1978. Report on a collection of sponges from the Bay of Naples. III. Hadromerida, Axinellida, Poecilosclerida, Halichondrida, Haplosclerida. Bollettino dei Musei e degli Istituti Biologici della (R.) Università di Genova 45: 7-89. 
Pulitzer-Finali G. 1983. A collection of Mediterranean Demospongiae (Porifera) with, in appendix, a list of the Demospongiae hitherto recorded from the Mediterranean Sea. Annali del Museo civico di storia naturale Giacomo Doria 84: 445-621.

Pulitzer-Finali G. 1993. A collection of marine sponges from East Africa. Annales Museo Civico Storia Naturale Giacomo Doria 89: 247-350.

Rezvoi P. 1924. Contribution towards the sponge fauna of the Kara and Barents Seas. Bulletin de l'Institut Lesshaft 8: 241-250. [in Russian with English summary]

Rezvoi P. 1928. Contribution to the fauna of Porifera in the Barents Sea. Transactions of the Institute for the scientific exploration of the North 37: 67-95. [In Russian with English summary.]

Ridley S.O. \& Dendy A. 1886. Preliminary report on the Monaxonida collected by H.M.S. 'Challenger'. Annals and Magazine of Natural History (5) 18: 325-351, 470-493. https://doi.org/10.1080/00222938609459982

Ridley S.O. \& Dendy A. 1887. Report on the Monaxonida collected by H.M.S. 'Challenger' during the years 1873-1876. Report on the Scientific Results of the Voyage of H.M.S. 'Challenger', 1873-1876, Zoology 20 (59): 1-275.

Samaai T. \& Gibbons M.J. 2005. Demospongiae taxonomy and biodiversity of the Benguela region on the west coast of South Africa. African Natural History 1: 1-96.

Schmidt O. 1870. Grundzüge einer Spongien-Fauna des atlantischen Gebietes. Wilhelm Engelmann, Leipzig.

Sim C.J. \& Kim M.H. 1988. A systematic study on the marine sponges in Korea. 7. Demospongiae and Hexactinellida. Korean Journal of Systematic Zoology 4 (1): 21-42.

Sitjà C. \& Maldonado M. 2014. New and rare sponges from the deep shelf of the Alboran Island (Alboran Sea, Western Mediterranean). Zootaxa 3760: 141-179. https://doi.org/10.11646/zootaxa.3760.2.2

Spalding M.D, Fox H.E., Allen G.E., Davidson N., Ferdaña Z.A., Finlayson M., Halperin B.S., Jorge M.A., Lombana A., Lourie S.A., Martin K.D., McManus E., Molnar J., Recchia C.A. \& Robertson J. 2007. Marine ecoregions of the world: a bioregionalization of coastal and shelf areas. BioScience 57 (7): 573-583. https://doi.org/10.1641/B570707

Stephens J. 1916. XX — Preliminary notice of some Irish Sponges.-The Monaxonellida (Suborder Sigmatomonaxonellida) obtained by the Fisheries Branch of the Department of Agriculture and Technical Instruction, Ireland. Annals and Magazine of Natural History (8) 17 (99): 232-242. https://doi.org/10.1080/00222931508693773

Stephens J. 1917. Report on the sponges collected off the coasts of Ireland by the dredging expeditions of the Royal Irish Academy and the Royal Dublin Society. Proceedings of the Royal Irish Academy 34 (B): 1-16.

Stephens J. 1921. Sponges of the Coasts of Ireland. II. The Tetraxonida (concluded). Scientific Investigations of the Fisheries Branch. Department of Agriculture for Ireland 1920 (2): 1-75.

Thiele J. 1903. Kieselschwämme von Ternate. II. Abhandlungen herausgegeben von der Senckenbergischen naturforschenden Gesellschaft 25: 933-968.

Topsent É. 1896. Éponges. In: Koehler R. (ed.) Scientific results of the Caudan campaign in the Gulf of Biscay, August-September 1895. Annales de l'Université de Lyon 26: 276-295.

Topsent É. 1904. Spongiaires des Açores. Résultats des campagnes scientifiques accomplies par le Prince Albert I. Monaco 25: 1-280. Available from http://biodiversitylibrary.org/page/2147461 [accessed 7 Sep. 2017]. 
Topsent É. 1928. Spongiaires de l'Atlantique et de la Méditerranée provenant des croisières du Prince Albert ler de Monaco. Résultats des campagnes scientifiques accomplies par le Prince Albert I. Monaco 74: 1-376.

Uriz M.J. 1987. Sponges from the South-West of Africa: description of species. In: Jones W.C. (ed.) European Contributions to the Taxonomy of Sponges: 54-73. Sherkin Island Marine Station, Sherkin Island, County Cork.

Uriz M.J. 1988. Deep-water sponges from the continental shelf and slope off Namibia (Southwest Africa): Classses Hexactinellida and Demospongia. Monografias de Zoología Marina 3: 9-157.

Vacelet J. 1969. Éponges de la roche du large et de l'étage bathyal de Méditerranée (Récoltes de la soucoupe plongeante Cousteau et dragages). Mémoires du Muséum national d'Histoire naturelle (A, Zoologie) 59 (2): 145-219, Muséum national d'Histoire naturelle, Paris.

Vacelet J., Vasseur P. \& Lévi C. 1976. Spongiaires de la pente externe des récifs coralliens de Tuléar (Sud-Ouest de Madagascar). Mémoires du Muséum national d'Histoire naturelle (A, Zoologie) 49, Muséum national d'Histoire naturelle, Paris.

Van Soest R.W.M. 1980. Marine sponges from Curaçao and other Caribbean localities. Part II. Haplosclerida. In: Hummelinck P.W. \& Van der Steen L.J. (eds) Uitgaven van de Natuurwetenschappelijke Studiekring voor Suriname en de Nederlandse Antillen. No. 104. Studies on the Fauna of Curaçao and other Caribbean Islands 62 (191): 1-173. Available from http://www.repository.naturalis.nl/record/506243 [accessed 25 Jul. 2017].

Van Soest R.W.M. 1984. Marine sponges from Curaçao and other Caribbean localities. Part III. Poecilosclerida. In: Hummelinck P.W. \& Van der Steen L.J. (eds) Uitgaven van de Natuurwetenschappelijke Studiekring voor Suriname en de Nederlandse Antillen. No. 112. Studies on the Fauna of Curaçao and other Caribbean Islands 66 (199): 1-167. Available from http://www.repository.naturalis.nl/record/506067 [accessed 25 Jul. 2017].

Van Soest R.W.M. 2017. Sponges of the Guyana Shelf. Zootaxa 4217 (1): 1-225. https://doi.org/10.11646/zootaxa.4217.1.1

Van Soest R.W.M., Cleary D.F.R., De Kluijver M.J., Lavaleye M.S.S., Maier C. \& Van Duyl F.C. 2007. Sponge diversity and community composition in Irish bathyal coral reefs. Contributions to Zoology 76 (2): 121-142. Available from http://www.repository.naturalis.nl/record/226534 [accessed 25 Jul. 2017].

Van Soest R.W.M., Beglinger E.J. \& De Voogd N.J. 2014. Mycale species (Porifera: Poecilosclerida) of Northwest Africa and the Macaronesian Islands. Zoölogische Mededelingen Leiden 88 (4): 59-109. Available from http://www.repository.naturalis.nl/record/516158 [accessed 25 Jul. 2017].

Van Soest R.W.M., Boury-Esnault N., Hooper J.N.A., Rützler K., De Voogd N.J., Alvarez de Glasby B., Hajdu E., Pisera A.B., Manconi R., Schoenberg C., Klautau M., Picton B., Kelly M., Vacelet J., Dohrmann M., Díaz M.C., Cárdenas P. \& Carballo J.L. 2016. World Porifera Database. Available from http://www.marinespecies.org/porifera/ [accessed 21 Sep. 2016].

Van Soest R.W.M., Stone S.M., Boury-Esnault B. \& Rützler K. 1983. Catalogue of the Duchassaing \& Michelotti (1864) collection of West Indian sponges (Porifera). Bulletin Zoölogisch Museum Universiteit van Amsterdam 9 (21): 189-206. Available from http://www.repository.naturalis.nl/record/505563 [accessed 25 Jul. 2017].

Vosmaer G.C.J. 1880. The Sponges of the Leyden Museum. 1. The family of the Desmacidinae. Notes from the Leyden Museum 2: 99-164. Available from http://www.repository.naturalis.nl/record/508716 [accessed 25 Jul. 2017]. 
Vosmaer G.C.J. 1885. The Sponges of the 'Willem Barents' Expedition 1880 and 1881. Bijdragen tot de Dierkunde 12 (3): 1-47. Available from http://www.repository.naturalis.nl/record/504555 [accessed 25 Jul. 2017].

Manuscript received: 23 October 2016

Manuscript accepted: 9 January 2017

Published on: 21 September 2017

Topic editor: Rudy Jocqué

Desk editor: Kristiaan Hoedemakers

Printed versions of all papers are also deposited in the libraries of the institutes that are members of the EJT consortium: Muséum national d'Histoire naturelle, Paris, France; Botanic Garden Meise, Belgium; Royal Museum for Central Africa, Tervuren, Belgium; Natural History Museum, London, United Kingdom; Royal Belgian Institute of Natural Sciences, Brussels, Belgium; Natural History Museum of Denmark, Copenhagen, Denmark; Naturalis Biodiversity Center, Leiden, the Netherlands; Museo Nacional de Ciencias Naturales-CSIC, Madrid, Spain; Real Jardín Botánico de Madrid CSIC, Spain. 